ARTICLE

\title{
From Ru-bda to Ru-bds: a step forward to highly efficient molecular water oxidation electrocatalysts under acidic and neutral conditions
}

\author{
Jing Yang ${ }^{1,7}$, Lei Wang (10 2,7, Shaoqi Zhan ${ }^{3,7}$, Haiyuan Zou', Hong Chen ${ }^{4}$, Mårten S. G. Ahlquist (id ${ }^{3}$, \\ Lele Duan (1) ${ }^{1,5 凶}$ \& Licheng Sun (10) $2,5,6 \times$
}

Significant advances during the past decades in the design and studies of Ru complexes with polypyridine ligands have led to the great development of molecular water oxidation catalysts and understanding on the $\mathrm{O}-\mathrm{O}$ bond formation mechanisms. Here we report a Ru-based molecular water oxidation catalyst $\left[\mathrm{Ru}(\mathrm{bds})(\mathrm{pic})_{2}\right]$ (Ru-bds; bds ${ }^{2-}=2,2^{\prime}$-bipyridine-6,6'disulfonate) containing a tetradentate, dianionic sulfonate ligand at the equatorial position and two 4-picoline ligands at the axial positions. This Ru-bds catalyst electrochemically catalyzes water oxidation with turnover frequencies (TOF) of 160 and $12,900 \mathrm{~s}^{-1}$ under acidic and neutral conditions respectively, showing much better performance than the stateof-art Ru-bda catalyst. Density functional theory calculations reveal that (i) under acidic conditions, the high valent $\mathrm{Ru}$ intermediate $\mathrm{Ru}^{\mathrm{V}}=\mathrm{O}$ featuring the 7-coordination configuration is involved in the $\mathrm{O}-\mathrm{O}$ bond formation step; (ii) under neutral conditions, the sevencoordinate $\mathrm{Ru}^{\mathrm{IV}}=\mathrm{O}$ triggers the $\mathrm{O}-\mathrm{O}$ bond formation; (iii) in both cases, the $\mathrm{I} 2 \mathrm{M}$ (interaction of two $\mathrm{M}-\mathrm{O}$ units) pathway is dominant over the WNA (water nucleophilic attack) pathway.

\footnotetext{
${ }^{1}$ Department of Chemistry, Shenzhen Grubbs Institute and Guangdong Provincial Key Laboratory of Energy Materials for Electric Power, Southern University of Science and Technology, Shenzhen 518055, People's Republic of China. ${ }^{2}$ Department of Chemistry, School of Engineering Sciences in Chemistry, Biotechnology and Health, KTH Royal Institute of Technology, 10044 Stockholm, Sweden. ${ }^{3}$ Department of Theoretical Chemistry \& Biology, School of Engineering Sciences in Chemistry, Biotechnology and Health, KTH Royal Institute of Technology, 10044 Stockholm, Sweden. ${ }^{4}$ School of Environmental Science \& Engineering, Southern University of Science and Technology, Shenzhen 518055, People's Republic of China. ${ }^{5}$ State Key Laboratory of Fine Chemicals, DUT - KTH Joint Education and Research Center on Molecular Devices, Dalian University of Technology (DUT), Dalian 116012, People's Republic of China. ${ }^{6}$ Center of Artificial Photosynthesis for Solar Fuels, School of Science, Westlake University, 310024 Hangzhou, China. ${ }^{7}$ These authors contributed

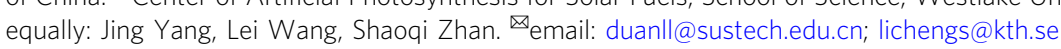


A rtificial photosynthesis is one of the most promising ways to build our society with sustainable energy systems while catalysis of water splitting is the key ${ }^{1}$. Two half-reactions are involved in the water-splitting process: water oxidation $\left(2 \mathrm{H}_{2} \mathrm{O} \rightarrow \mathrm{O}_{2}+4 \mathrm{H}^{+}+4 \mathrm{e}^{-}\right)$and proton reduction $\left(4 \mathrm{H}^{+}+4 \mathrm{e}^{-}\right.$ $\left.\rightarrow 2 \mathrm{H}_{2}\right)$. The first half reaction is widely regarded as the bottleneck of total water splitting. To date, only Ir-based catalysts display high catalytic activity and long durability towards electrochemical water oxidation under strongly acidic conditions $s^{2,3}$. The majority of noble-metal free water oxidation catalysts (WOCs) are confined under strong alkaline conditions whereas they show only moderate performances under neutral conditions and quickly deactivate in acidic media ${ }^{4-6}$. In contrast, molecular WOCs displayed their advantages over the majority of metal oxides with regard to stability and catalytic activity under acidic conditions. In the last decade, a great number of WOCs based on transition metal complexes such as $\mathrm{Fe}^{7-9}, \mathrm{Ir}^{10}, \mathrm{Co}^{11,12}, \mathrm{Mn}^{13,14}$, $\mathrm{Cu}^{15,16}$ and $\mathrm{Ru}^{17-20}$ have been reported, among which $\mathrm{Ru}$-based WOCs with relatively simple polypyridyl ligands are the most representative due to their adequate stability and high catalytic activity under strongly acidic conditions ${ }^{21-23}$.

Inspired by the first Ru-based WOC, $\left[(\text { bpy })_{2}\left(\mathrm{H}_{2} \mathrm{O}\right) \mathrm{Ru}^{\mathrm{III}} \mathrm{ORu}{ }^{\mathrm{III}}\right.$ $\left.\left(\mathrm{OH}_{2}\right)(\mathrm{bpy})_{2}\right]\left(\mathrm{ClO}_{4}\right)_{4}$ (bpy $=2,2^{\prime}$-bipyridine), reported by Meyer et al. in $1982^{24}$, many other Ru WOCs have been developed recently ${ }^{25,26}$, such as $\mathbf{R u}-\mathbf{H b p p}\left(\mathrm{Hbpp}^{-}=3,5\right.$-bis(2-pyridyl) pyrazolate ${ }^{27}$ by Llobet and Ru-bnp (bnp $=4$-tert-Butyl-2,6-di $\left(\left[1^{\prime}, 8^{\prime}\right]\right.$-naphthyrid-2'-yl)pyridine) by Thummel ${ }^{28}$. The mononuclear $\mathrm{Ru}$ catalysts, $\left[\mathrm{Ru}(\mathrm{bda})(\mathrm{L})_{2}\right] \quad\left(\mathbf{R u}-\mathbf{b d a} ; \mathrm{H}_{2} \mathrm{bda}=2,2^{\prime}\right.$ bipyridine-6,6'-dicarboxylic acid; $\mathrm{L}=\mathrm{N}$-heterocyclic ligands; Fig. 1), first developed by the Sun group, are among the most efficient molecular WOCs ${ }^{17,21}$. This type of catalysts catalyze the $\mathrm{O}-\mathrm{O}$ bond formation via the $\mathrm{I} 2 \mathrm{M}$ (interaction of two $\mathrm{M}-\mathrm{O}$ units) pathway. Later, Llobet and co-workers reported a Ru-tda WOC (Fig. 1) with catalytic current density of $4.8 \mathrm{~mA} / \mathrm{cm}^{2}$ at $1.56 \mathrm{~V}$ under pH 7.0 conditions ${ }^{29}$. Recently, Concepcion and coworkers modified the $\mathrm{bda}^{2-}$ ligand by introducing phosphate groups instead of carboxylate groups and prepared complexes Ru-bpaH ${ }_{2}$ (Fig. 1) and $\left[\mathrm{Ru}(\mathrm{bpHc})(\mathrm{L})_{2}\right]\left(\mathrm{bpHc}^{2-}=6^{\prime}\right.$-phosphono-[2,2'-bipyridine]-6-carboxylate) with more or less enhanced activity ${ }^{30-32}$. The Ru-bda is very efficient with cerium (IV) ammonium nitrate $\left(\left(\mathrm{NH}_{4}\right)_{2}\left[\mathrm{Ce}^{\mathrm{IV}}\left(\mathrm{NO}_{3}\right)_{6}\right]\right)$ as a sacrificial chemical oxidant. However, its electocatalytic performance is not among the best reported so far. Previous studies on the Ru-bda catalysts revealed that electron-withdrawing groups on the axial ligands could enhance water oxidation activity ${ }^{33}$.

In this work, by changing the carboxylate ligand to a less electron-donating sulfonate ligand, 2,2'-bipyridine-6,6'-disulfonate $\left(\mathrm{bds}^{2-}\right)$, we invent a type of highly efficient water oxidation electrocatalyst, $\left[\mathrm{Ru}(\mathrm{bds})(\text { pic })_{2}\right](\mathbf{R u}$-bds; pic $=4$-picoline;
Fig. 1), that reaches turnover frequencies (TOF) of 160 and $12900 \mathrm{~s}^{-1}$ at $\mathrm{pH} 1.0$ and 7.0 conditions respectively, which outperforms most reported $\mathrm{Ru}$ catalysts under similar conditions ${ }^{21,29,30}$, including the typical Ru-bda.

\section{Results and discussion}

Synthesis and characterization. The ligand $\mathrm{H}_{2}$ bds was prepared by the nucleophilic substitution of the bromo groups on $6,6^{\prime}$ dibromo-2,2'-bipyridine by NaHS at elevated temperature, followed by the oxidation of the hydrosulfide groups by $\mathrm{HNO}_{3}$ to obtain the desired sulfonate containing ligand $\mathrm{H}_{2}$ bds. Subsequent coordination of the $\mathrm{H}_{2}$ bds ligand to $\left[\mathrm{Ru}(p \text {-cymene }) \mathrm{Cl}_{2}\right]_{2}$ in the presence of $\mathrm{NEt}_{3}$, followed by reaction with 4-picoline yields the corresponding mononuclear catalyst Ru-bds. The ${ }^{1} \mathrm{H} /{ }^{13} \mathrm{C}$ NMR and ${ }^{1} \mathrm{H}^{1} \mathrm{H}$ COSY spectra of $\mathrm{H}_{2}$ bds and Ru-bds were shown in Supplementary Figs. 1-8.

The Ru-bds crystallizes with two chemically identical but crystallographically distinct molecules in the asymmetric unit. One of the X-ray crystal structures was depicted in Fig. 2, and the $\mathrm{Ru}$ centre is in a typical distorted octahedral geometry. It is noticeable that the O3-Ru1-O4 bite angle of Ru-bds $\left(114.7(3)^{\circ}\right)$ is slightly larger than that of previously reported $\mathbf{R u}^{\mathrm{III}}-\mathbf{b p a H}_{2}(112.09$ $\left.(6)^{\circ}\right)^{30}$ whereas smaller than that of $\mathbf{R u}^{\mathrm{II}}-\mathbf{b d a}\left(123.0(2)^{\circ}\right)^{17}$, all of which are significantly larger than the ideal $90^{\circ}$ of an octahedron configuration. The wide $\mathrm{O}-\mathrm{Ru}-\mathrm{O}$ angle provides the open site of the catalyst for substrate water binding and favors the formation of seven-coordinate $\mathrm{Ru}$ intermediates during the catalytic process of water oxidation. Noteworthy, as depicted in Supplementary Fig. 9, the $\mathrm{C} 19-\mathrm{C} 18-\mathrm{C} 17$ angle of $127.1(8)^{\circ}$ in Ru-bds is a little bit smaller than C8-C7-C6 $\left(129.6(7)^{\circ}\right)$ in Ru-bda, showing that the bipyridine ring of Ru-bds is less distorted in comparison with that of Ru-bda. Thereby, the bds ${ }^{2-}$ ligand backbone fits the $\mathrm{Ru}^{\mathrm{II}}$ cation slightly better than the $\mathrm{bda}^{2-}$ ligand.

The ${ }^{1} \mathrm{H}$ NMR spectrum of Ru-bds in $\mathrm{CD}_{2} \mathrm{Cl}_{2} / \mathrm{CD}_{3} \mathrm{OD}$ (Supplementary Fig. 10a) is in agreement with a $C_{2 v}$ symmetry of its chemical structure. Two doublets at 8.53 and $8.09 \mathrm{ppm}$ and one triplet at $7.98 \mathrm{ppm}$ were assigned to the proton resonances of the equatorial bds ${ }^{2-}$ ligand while two-resonance peaks at 7.82 and $7.03 \mathrm{ppm}$ to two axial 4-picoline ligands. When the mixed $\mathrm{CD}_{3} \mathrm{CN} / \mathrm{D}_{2} \mathrm{O}$ was used as the solvent, four broad proton resonances originating from the equatorial ligand appeared while two doublets of the 4-picoline protons remained but slightly downshifted to 8.00 and $7.19 \mathrm{ppm}$, pointing to a loss of $C_{2 v}$ symmetry (Supplementary Fig. 10b). This is attributed to the formation of acetonitrile-coordinating complex, $\left[\mathrm{Ru}\left(k_{3} \mathrm{O}, \mathrm{N}, \mathrm{N}_{-}-\mathrm{bds}\right)\right.$ $\left.(\mathrm{pic})_{2}\left(\mathrm{CH}_{3} \mathrm{CN}\right)\right]$ with a dangling sulfonate arm. Similar dissociation of the equatorial ligand, such as carboxylate group, was found occurring as well for Ru-bda ${ }^{34}$ and Ru-pda $\left(\mathrm{H}_{2}\right.$ pda is 1, 10-phenanthroline-2,9-dicarboxylic acid) ${ }^{35}$. Labile carboxylate

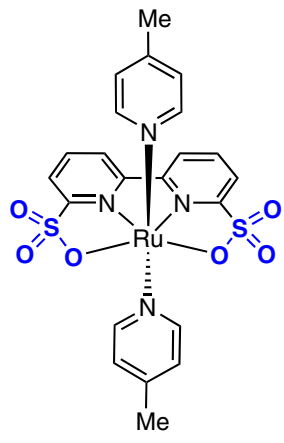

Ru-bds

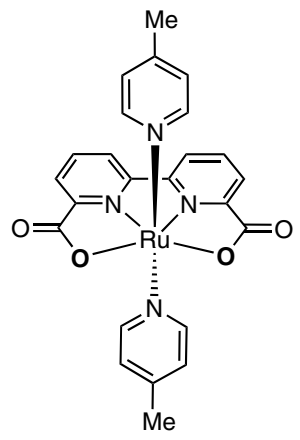

Ru-bda

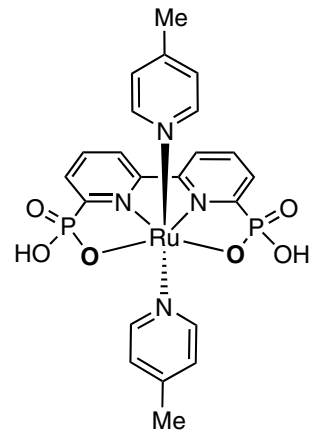

Ru-bpaH 2

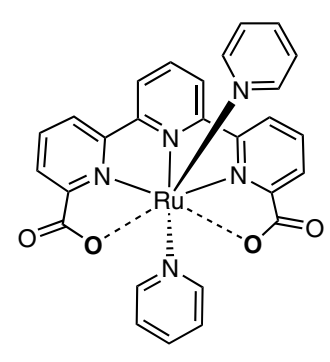

Ru-tda

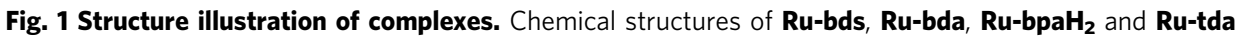




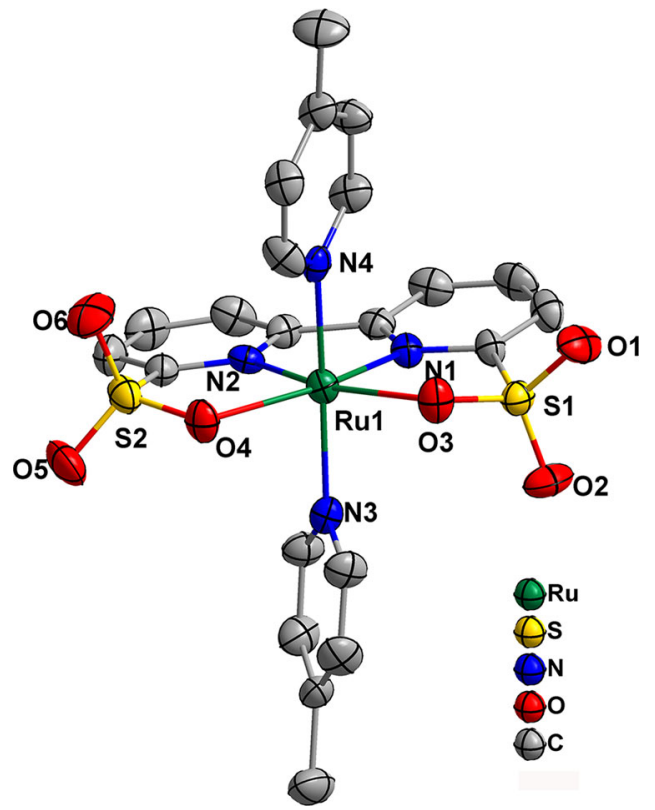

Fig. 2 X-ray crystal structure. The X-ray crystal structure of Ru-bds with thermal ellipsoids at $50 \%$ probability (hydrogen atoms are omitted for clarity).

chelation is important for water substrate coordinating to the metal center at $\mathrm{Ru}^{\mathrm{III}}$ states $^{21}$. Thus, the sulfonate chelation in $\mathbf{R u}$ bds should also promote the water coordination to $\mathrm{Ru}^{\mathrm{III}}$ center and facilitate the further water oxidation steps.

The catalytic performance of this $\mathbf{R u}$-bds under $\mathrm{Ce}^{\mathrm{IV}}$-driven water oxidation conditions is less effective but more durable than Ru-bda (Supplementary Fig. 11). Kinetic measurements revealed that the oxygen evolution is a first order reaction in regard to both catalyst (Supplementary Fig. 12) and $\mathrm{Ce}^{\mathrm{IV}}$ (Supplementary Fig. 13) concentrations, meaning that the rate-determining step is an oxidation step, likely $\mathrm{Ru}^{\mathrm{IV}}-\mathrm{OH}$ to $\mathrm{Ru}^{\mathrm{V}}=\mathrm{O}$. The low activity is due to the small driving force of $\mathrm{Ce}^{\mathrm{IV}}\left(E\left(\mathrm{Ce}^{\mathrm{IV} / \mathrm{III}}\right)=1.6 \mathrm{~V}\right.$ vs. $\mathrm{NHE}^{36}$; all potentials herein are reported versus normal hydrogen electrode, NHE) in comparison with the catalytic onset potential of Ru-bds $\left(E_{\text {onset }}=1.6\right.$ $\mathrm{V}$; vide infra). We thereby studied the electrochemical driven water oxidation by $\mathbf{R u}$-bds in the rest of this work.

Electrochemistry under acidic conditions. First, the electrochemistry of Ru-bda and Ru-bds was studied in pH 1.0 triflic acid aqueous solutions with $20 \% \mathrm{CH}_{3} \mathrm{CN}$ (to improve the solubility of Ru-bds; it should be noted that acetonitrile competes with water accessing the Ru center and thereby suppresses water oxidation activity ${ }^{23}$ ). As shown in Fig. $3 a$ and Supplementary Fig. 14, Ru-bda displays three redox waves at $0.89,1.12$ and 1.33 $\mathrm{V}$, which are related to three consecutive metal-based one-electron oxidation processes: $\mathrm{Ru}^{\mathrm{II}}-\mathrm{NCCH}_{3} \rightarrow \mathrm{Ru}^{\mathrm{III}}-\mathrm{OH}_{2} \rightarrow \mathrm{Ru}^{\mathrm{IV}}$ $-\mathrm{OH} \rightarrow \mathrm{Ru}^{\mathrm{V}}=\mathrm{O}$, respectively. A small increase in the current density of roughly $0.6 \mathrm{~mA} / \mathrm{cm}^{2}$ in the $1.5-1.8 \mathrm{~V}$ zone indicates slow catalytic water oxidation. Nevertheless, a substantial enhancement of catalytic current density was observed from the CV curve of Ru-bds under the acidic conditions (Fig. 3a) reaching a value of $1.48 \mathrm{~mA} / \mathrm{cm}^{2}$ at $1.74 \mathrm{~V}$. The consecutive oxidation processes of $\mathbf{R u}$-bds were assigned according to the potential versus $\mathrm{pH}$ diagram (Supplementary Fig. 15; vide infra). The first redox wave is clearly visible at $1.18 \mathrm{~V}$, attributed to the single electron process of $\mathrm{Ru}^{\mathrm{II}}-\mathrm{NCCH}_{3} \rightarrow \mathrm{Ru}^{\mathrm{III}}-\mathrm{OH}_{2}$. The second, irreversible oxidation wave at $1.41 \mathrm{~V}$ is corresponding to $\mathrm{Ru}^{\mathrm{III}}-\mathrm{OH}_{2} \rightarrow \mathrm{Ru}^{\mathrm{IV}}-\mathrm{OH}$. Oxidation of $\mathrm{Ru}^{\mathrm{IV}}-\mathrm{OH}$ to $\mathrm{Ru}^{\mathrm{V}}=\mathrm{O}$
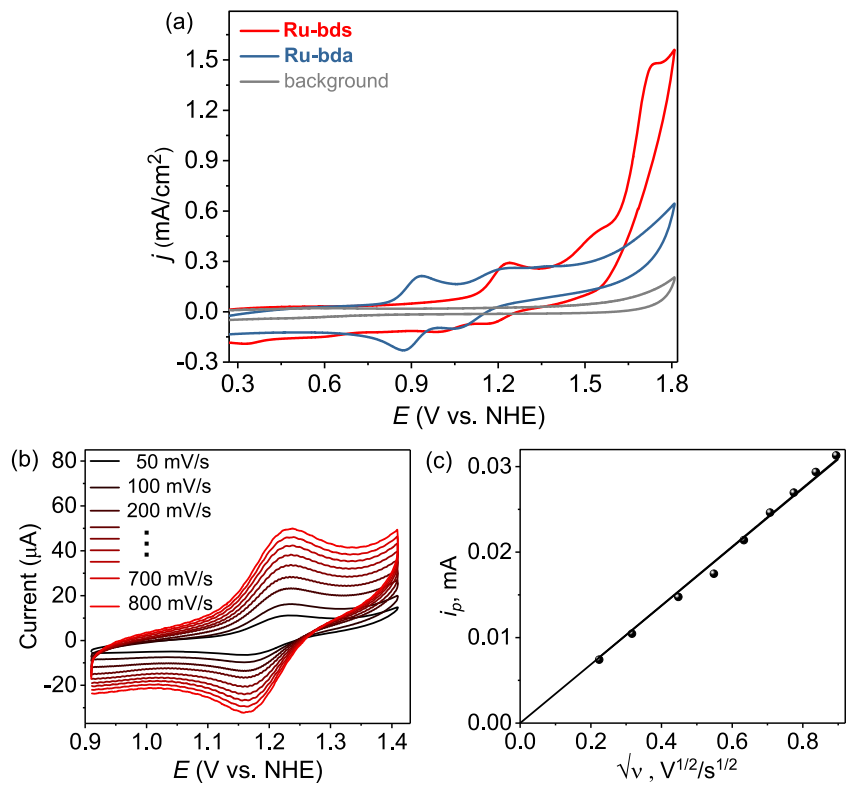

Fig. 3 Electrochemical behavior under acidic conditions. a CVs of $1.0 \mathrm{mM}$ Ru-bda and Ru-bds in pH 1.0 triflic acid aqueous solution containing 20\% volume $\mathrm{CH}_{3} \mathrm{CN}$ with scan rate of $100 \mathrm{mV} \mathrm{s}^{-1}$ (the diameter of glassy carbon working electrode is $3 \mathrm{~mm}$ ). b CV scan rate dependence with $1.0 \mathrm{mM}$ Ru-bds from 0.91 to $1.41 \mathrm{~V}$ and scan rate varies from 50 to $800 \mathrm{mV} \mathrm{s}^{-1}$. c Dependence of the peak current for the Rulll/II couple $\left(E_{1 / 2}=1.18 \mathrm{~V}\right)$ on the square root of scan rate.

$(1.58 \mathrm{~V})$ triggers electrochemical water oxidation. All redox states are about $0.3 \mathrm{~V}$ higher relative to $\mathbf{R u}-\mathbf{b d a}$, which is, as expected, due to the relatively less electron-donating ability of the sulfonate group than the carboxylate group.

The $\mathrm{Ru}^{\mathrm{III} / \mathrm{II}}$ redox couples of $\mathbf{R u}$-bds at various scan rates are depicted in Fig. $3 \mathrm{~b}$ and its peak current $\left(i_{\mathrm{p}}\right)$ varies linearly with the square root of scan rate $\left(v^{1 / 2}\right)$, indicating a diffusion controlled electrochemical process (Fig. 3c). According to the Randles-Sevcik equation (Eq. 1; F is the Faraday constant, $\mathrm{A}$ is the electrode area, $\left[\mathrm{Ru}^{\mathrm{II}}\right]$ is the bulk concentration of catalyst, $\mathrm{n}_{\mathrm{p}}=1$ is the number of electrons transferred, $\mathrm{n}_{\text {cat }}=4$ is the number of electrons required to complete a single catalytic cycle, $\mathrm{D}$ is the diffusion constant of catalyst, $\mathrm{R}$ is the ideal gas constant, and $\mathrm{T}$ is the temperature), the diffusion co-efficient was $5.02 \times 10^{-6} \mathrm{~cm}^{2} \mathrm{~s}^{-1}$. CV scans of Ru-bds and Ru-bda at various scan rates are plotted in Fig. $4 a, b$. The catalytic currents becomes relatively scan rate independent at $1.5 \mathrm{~V} \mathrm{~s}^{-1}$ for $\mathbf{R u}$-bds and $2.1 \mathrm{~V} \mathrm{~s}^{-1}$ for $\mathbf{R u}$-bda, indicating steady-state conditions are accomplished at such these high scan rates. According to the ratio of $i_{\text {cat }}$ vs. the noncatalytic Faradaic current $\left(i_{\mathrm{p}}\right)$ using an established method with the Eq. $3^{37}$, the TOF value of $\mathbf{R u}$-bds is calculated to be $160 \mathrm{~s}^{-1}$ at a scan rate of $1.5 \mathrm{~V} \mathrm{~s}^{-1}$ toward electrochemical water oxidation whereas Ru-bda displays a TOF of $7 \mathrm{~s}^{-1}$ at a scan rate of $2.1 \mathrm{~V} \mathrm{~s}^{-1}$. Given the above results, Ru-bds is surpassing the wellknown mononuclear reference Ru-bda catalyst towards electrochemical water oxidation under acidic conditions.

$$
\begin{gathered}
i_{p}=0.446 \mathrm{n}_{p} \mathrm{FA}\left[\mathrm{Ru}^{\mathrm{II}}\right]\left(\mathrm{n}_{p} \mathrm{~F} v D / \mathrm{RT}\right)^{1 / 2} \\
i_{\mathrm{cat}}=\mathrm{n}_{\mathrm{cat}} \mathrm{FA}\left[\mathrm{Ru}^{\mathrm{II}}\right]\left(\mathrm{D} k_{\mathrm{cat}}\right)^{1 / 2} \\
\mathrm{TOF}=0.1992\left(\frac{\mathrm{Fv}}{\mathrm{RT}}\right)\left(\frac{n_{p}^{3}}{n_{\mathrm{cat}}^{2}}\right)\left(\frac{i_{\mathrm{cat}}}{i_{p}}\right)^{2}
\end{gathered}
$$



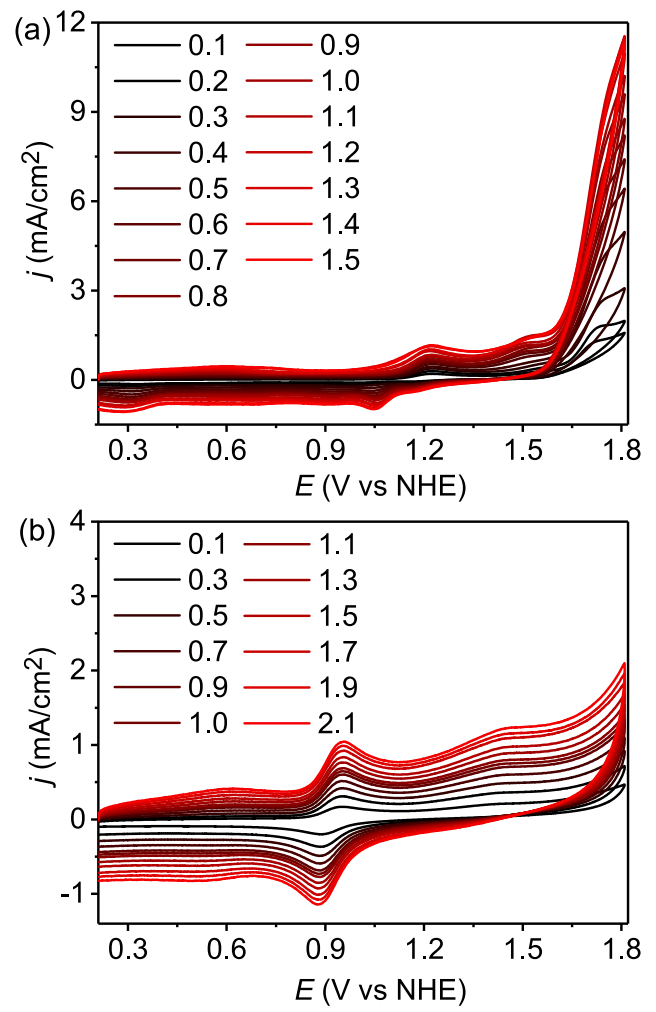

Fig. 4 Electrochemistry under acidic conditions. a CVs of Ru-bds in $\mathrm{pH}$ $1.0 / \mathrm{CH}_{3} \mathrm{CN}$ at different scan rates from 0.1 to $1.5 \mathrm{~V} \mathrm{~s}^{-1}$. $\mathbf{b} \mathrm{CVs}$ of $\mathbf{R u}$-bda in $\mathrm{pH} 1.0 / \mathrm{CH}_{3} \mathrm{CN}$ at different scan rates from 0.1 to $2.1 \mathrm{~V} \mathrm{~s}^{-1}$. Note: $i_{\text {cat }}$ values at $1.78 \mathrm{~V}$ were used to calculate the TOF for both Ru-bds and Ru-bda.

To provide more insights into these redox processes and the electronic effect of the equatorial bds ${ }^{2-}$ ligand on the redox properties, the potential versus $\mathrm{pH}$ diagram (Pourbaix diagram) of Ru-bds was constructed and shown in Supplementary Fig. 15. The potential of the first oxidation step is constant to be ca. 1.18 $\mathrm{V}$ up to $\mathrm{pH}$ 3.2. The $\mathrm{pH}$ independence indicates that only electron transfer is involved in the first oxidation, corresponding to the oxidation of $\mathrm{Ru}^{\mathrm{II}}-\mathrm{NCCH}_{3}$ to 6-coordinate $\mathrm{Ru}^{\mathrm{III}}-\mathrm{OH}_{2}$, [ $\left[\mathrm{Ru}^{\mathrm{III}}\right.$ $\left(k_{3} \mathrm{O}, \mathrm{N}, \mathrm{N}_{-}\right.$-bds $\left.)(\mathrm{pic})_{2}\left(\mathrm{OH}_{2}\right)\right]^{+}$. Therefore, the $\mathrm{p} K_{\mathrm{a}}$ value of $\mathrm{Ru}^{\mathrm{III}}$ $-\mathrm{OH}_{2}$ was determined to be 3.2 , which is much smaller than the $\mathrm{p} K_{\mathrm{a}}$ value of 5.5 in $\mathbf{R u}-\mathbf{b d a} \mathbf{a}^{21}$; this is further in accordance with the relatively poor electron-donating ability of the sulfonate group compared with the carboxylate group. As the $\mathrm{pH}$ increases from 3.2 all the way to 8.1 , the $\mathrm{Ru}^{\mathrm{III} / \mathrm{II}}$ redox couple decreases linearly as the solution $\mathrm{pH}$ increases with of a slope $-53 \mathrm{mV}$ per $\mathrm{pH}$, corresponding to typical proton-coupled electron transfer (PCET) process and assigned to the oxidation of $\mathrm{Ru}^{\mathrm{II}}-\mathrm{NCCH}_{3}$ to $\mathrm{Ru}^{\mathrm{III}}-\mathrm{OH}$. For the $\mathrm{Ru}^{\mathrm{IV} / \mathrm{III}}$ redox couple, as evidenced by a slope of $-64 \mathrm{mV}$ per $\mathrm{pH}$ over the range from $\mathrm{pH} 1.18$ to 3.2, the PCET process can be ascribed to the oxidation of $\mathrm{Ru}^{\mathrm{III}}-\mathrm{OH}_{2}$ to $\mathrm{Ru}^{\mathrm{IV}}$ $-\mathrm{OH}$. Unfortunately, this redox event became too weak to be distinguished at $\mathrm{pH}>3.0$ and meanwhile it is overlapped with the catalytic current; thereby, the corresponding potential values were obtained by measuring the potential values at $3.0 \times 10^{-5} \mathrm{~mA}$ for each scan. The potential of the $\mathrm{Ru}^{\mathrm{IV} / \mathrm{III}}$ is constant to be $1.26 \mathrm{~V}$ from $\mathrm{pH} 3.2$ to 5.3 , which is related to the process of $\mathrm{Ru}^{\mathrm{III}}-\mathrm{OH}$ to $\mathrm{Ru}^{\mathrm{IV}}-\mathrm{OH}$ with only electron transfer. As the $\mathrm{pH}$ increase from 5.3 to 8.1 , there is a PCET process belonging to the oxidation process of $\mathrm{Ru}^{\mathrm{III}}-\mathrm{OH}$ to $\mathrm{Ru}^{\mathrm{IV}}=\mathrm{O}$. For the $\mathrm{Ru}^{\mathrm{IV}}-\mathrm{OH}$ species produced under acidic conditions, its oxidation via the PCET process leads to the formation of $\mathrm{Ru}^{\mathrm{V}}=\mathrm{O}$, a highly oxidizing state. Additionally, the CV of Ru-bds in $\mathrm{D}_{2} \mathrm{O}$ containing $0.1 \mathrm{M}$ triflic
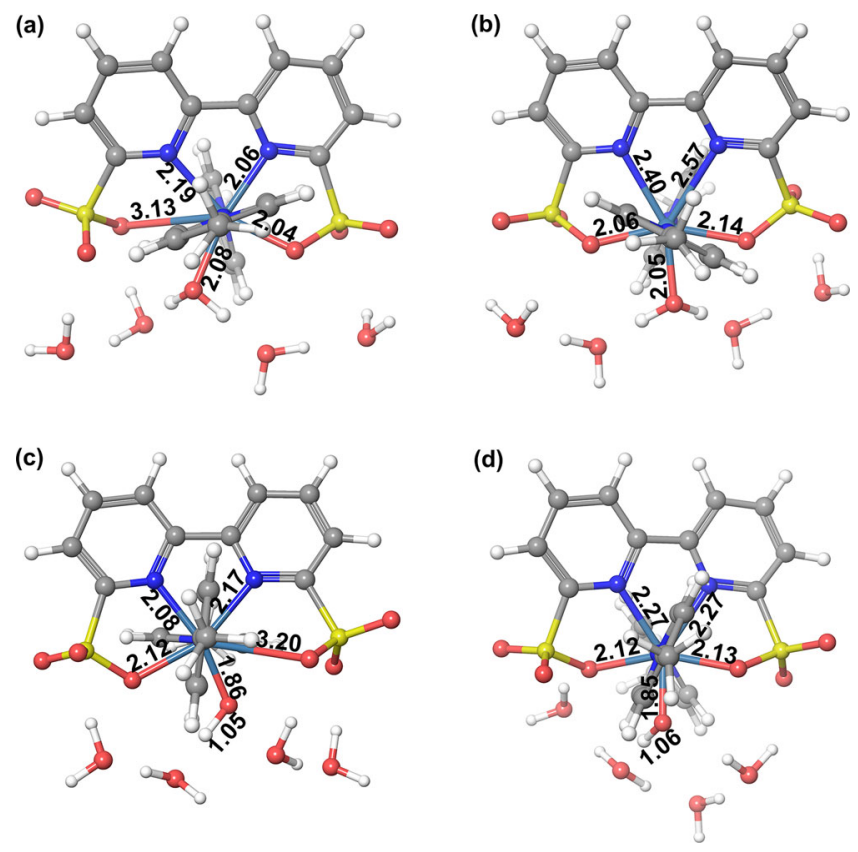

Fig. 5 DFT optimized structures. DFT optimized geometries for the structure conversion of $\left[\mathrm{Ru}^{\mathrm{III}}-\mathrm{OH}_{2}\right]^{+}$between a 6-coordination and b 7-coordination configurations, and $\left[\mathrm{Ru}^{\mathrm{IV}}-\mathrm{OH}\right]^{+}$between c 6-coordination and $\mathbf{d} 7$-coordination configurations. The bond lengths are given in $\AA$.

acid was also recorded (Supplementary Fig. 18) and the wave of $\mathrm{Ru}^{\mathrm{III}}-\mathrm{OH}_{2}$ to $\mathrm{Ru}^{\mathrm{IV}}-\mathrm{OH}$ is too weak to be observed, indicating the slow kinetics of $\mathrm{Ru}^{\mathrm{IV}}-\mathrm{OH}$ formation and thus its low concentration on the electrode surface.

The chronoamperometric curve of Ru-bds renders a moderate decay with $42 \%$ retention of the initial current density after $2 \mathrm{~h}$ bulk electrolysis in $\mathrm{pH} 1.0$ (Supplementary Fig. 19). The corresponding Faradaic efficiency was recorded to be 95\%. The post-electrolyzed CVs (Supplementary Fig. 20) demonstrated a two-third peak current loss for $\mathrm{Ru}^{\mathrm{III} / \mathrm{II}}$ associated with the catalytic current density declined (from 0.77 to $0.41 \mathrm{~mA} \mathrm{~cm}^{-2}$ at $1.7 \mathrm{~V})$. After bulk electrolysis, Ru-bds species is still the dominated species, as shown in the HRMS spectra (Supplementary Figs. 21-24), along with the appearance of several new signals with weak intensity, which are presumably structureevolved Ru-intermediates and probably contributed to the new redox waves in CVs.

Density functional theory (DFT) calculations. DFT calculations were performed to understand the reason on the high electrochemical driven water oxidation performance of Ru-bds and the reaction mechanism behind. As described in the previous study ${ }^{38}$, four extra water molecules were added around the metal complex to produce a reasonable hydrogen-bonding network. The calculated potential for the couple $\left[\mathrm{Ru}^{\mathrm{II}}\right] /\left[\mathrm{Ru}^{\mathrm{III}}-\mathrm{OH}_{2}\right]^{+}$at $\mathrm{pH} 1.0$ is $1.15 \mathrm{~V}$, which is close to the experimental value of $1.18 \mathrm{~V}$. Both structures of 6-coordinate $\left[\mathrm{Ru}^{\mathrm{III}}\left(k_{3} \mathrm{O}, \mathrm{N}, \mathrm{N}_{-} \text {-bds }\right)(\mathrm{pic})_{2}\left(\mathrm{OH}_{2}\right)\right]^{+}$and 7-coordinate $\left[\mathrm{Ru}^{\mathrm{III}}(\mathrm{bds})(\mathrm{pic})_{2}\left(\mathrm{OH}_{2}\right)\right]^{+}$were optimized (Fig. 5a, b). The Gibbs free energy of the 6 -coordination mode is $6.7 \mathrm{kcal}$ $\mathrm{mol}^{-1}$ lower than that of the 7-coordination. The formation of $\mathrm{Ru}$ aqua species plays a vital role for water oxidation because it can facilitate further oxidation of the $\mathrm{Ru}$ catalyst to higher oxidation states via the PCET process. Upon oxidation of the $\mathrm{Ru}^{\mathrm{III}}$ aqua species via a PECT process, $\left[\mathrm{Ru}^{\mathrm{IV}}-\mathrm{OH}\right]^{+}$is formed. The 7coordinate $\left[\mathrm{Ru}^{\mathrm{IV}}(\mathrm{bds})(\mathrm{pic})_{2}(\mathrm{OH})\right]^{+}$(Fig. 5d) becomes more stable than the corresponding 6-coordinate mode $\left[\mathrm{Ru}^{\mathrm{IV}}\left(k_{3} \mathrm{O}, \mathrm{N}, \mathrm{N}_{-}\right.\right.$ bds $\left.)(\text { pic })_{2}(\mathrm{OH})\right]^{+}$(Fig. 5c) by a Gibbs free energy difference of 

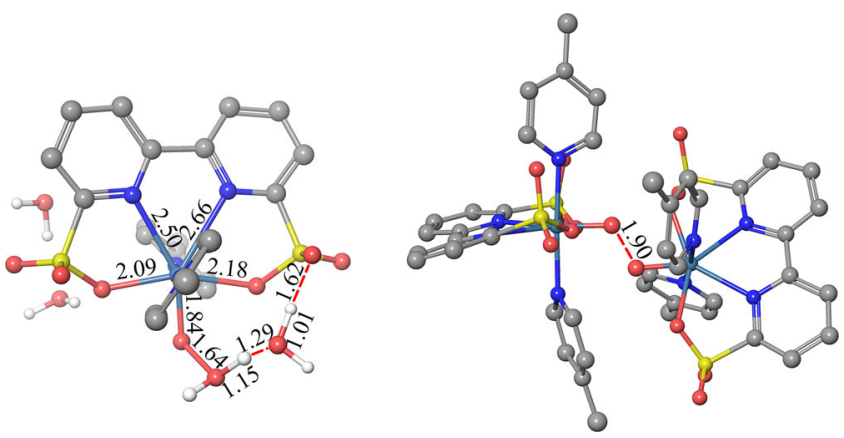

Fig. 6 DFT optimized structures. The transition state structures of WNA (left) and I2M (right) pathway. $\mathrm{H}$ atoms except those bonding in water molecules are omitted for clarity. The bond lengths are given in $\AA$.

$13.3 \mathrm{kcal} \mathrm{mol}^{-1}$. The corresponding redox potential of $\left[\mathrm{Ru}^{\mathrm{III}}\right.$ $\left.-\mathrm{OH}_{2}\right]^{+}{ }_{7 \text {-coordinate }} /\left[\mathrm{Ru}^{\mathrm{IV}}-\mathrm{OH}\right]^{+}{ }_{7 \text {-coordinate }}$ is $1.56 \mathrm{~V}$, which is $0.29 \mathrm{~V}$ lower than that of 6 -coordinate $\left[\mathrm{Ru}^{\mathrm{III}}-\mathrm{OH}_{2}\right]^{+}$. Further oxidation of $\left[\mathrm{Ru}^{\mathrm{IV}}-\mathrm{OH}\right]^{+}$leads to the formation of $\left[\mathrm{Ru}^{\mathrm{V}}=\mathrm{O}\right]^{+}$ with a calculated oxidation potential of $1.85 \mathrm{~V}$ at $\mathrm{pH} 1.0$, compared to the experimental value of $1.58 \mathrm{~V}$.

After the formation of $\left[\mathrm{Ru}^{\mathrm{V}}=\mathrm{O}\right]^{+}$, the $\mathrm{O}-\mathrm{O}$ bond formation step was calculated via both WNA and I2M pathways (Supplementary Fig. 25) and their corresponding transition states are shown in Fig. 6 . The computed activation free energy of the reaction via the WNA pathway is $15.5 \mathrm{kcal} \mathrm{mol}^{-1}$ and the reaction free energy is $-3.6 \mathrm{kcal} \mathrm{mol}^{-1}$. For the $\mathrm{I} 2 \mathrm{M}$ pathway, the full reaction includes diffusion of two $\left[\mathrm{Ru}^{\mathrm{V}}=\mathrm{O}\right]^{+}$species, encountering of two $\left[\mathrm{Ru}^{\mathrm{V}}=\mathrm{O}\right]^{+}$species to form the prereactive dimer and the radical coupling reaction in the full solvent ${ }^{39-41}$. The computed activation free energy for the radical coupling step is $6.9 \mathrm{kcal} \mathrm{mol}^{-1}$ from the prereactive dimer to the transition state, and the reaction free energy is $-11.5 \mathrm{kcal} \mathrm{mol}^{-1}$. The encoutering step of two species was found to have a key role for the different catalytic reactivities of $\mathbf{R u}$-bda complexes. We therefore parameterized $\left[\mathrm{Ru}^{\mathrm{V}}=\mathrm{O}\right]^{+}$model according to our published report ${ }^{41}$ and tested stability of the model (Supplementary Fig. 26). Based on the analysis of the hydrogen bonding (Supplementary Fig. 27), the oxo of $\left[\mathrm{Ru}^{\mathrm{V}}=\mathrm{O}\right]^{+}$of $\mathbf{R u}$-bds is found to be hydrophobic, similar to the oxo of Ru-bda. We performed potential of mean force (PMF) simulations to estimate the binding free energy of the prereactive dimer in water phase. The calculated binding free energy of the two $\left[\mathrm{Ru}^{\mathrm{V}}=\mathrm{O}\right]^{+}$species in water phase is $-4 \mathrm{kcal} \mathrm{mol}^{-1}$ (Supplementary Fig. 28), leading to a total activation energy of $2.6 \mathrm{kcal} \mathrm{mol}^{-1}$ for $\mathbf{R u}$-bds (the forward activation free energy of the $\mathrm{O}-\mathrm{O}$ bond formation minus the free energy of the dissociation of two species; Supplementary Table 2) for the full dimerization. Apparently, the I2M pathway is feasible for Ru-bds. In comparison, the activation energy of Rubds is slightly lower than that of $\mathbf{R u}-\mathbf{b d a}\left(3.9 \mathrm{kcal} \mathrm{mol}^{-1}\right)^{40}$.

Proposed mechanism. On the basis of the above electrochemistry, mass spectrometry, kinetics studies together with DFT calculations, the reaction mechanism of water oxidation by $\mathbf{R u}-$ bds under acidic conditions is proposed and depicted in Fig. $7^{42}$.

Base-enhanced catalytic water oxidation. As shown previously by Meyer and co-workers for the base-enhanced PECT oxidation, the role of the added buffer base was explored by CVs of Ru-bds $(1.0 \mathrm{mM})$ at $\mathrm{pH} 7.0$ while maintaining the ionic strength at $0.5 \mathrm{M}$ (compensated by $\mathrm{NaNO}_{3}$, Supplementary Fig. 31). Significant acceleration of catalytic current is achieved toward water oxidation as the total concentration of $\mathrm{H}_{2} \mathrm{PO}_{4}^{-} / \mathrm{HPO}_{4}^{2-}$ buffers increases gradually from $0.01 \mathrm{M}$ to $0.2 \mathrm{M}$, during which a wave with nearly plateau shape was observed at the lowest buffer concentration where a maximum current reached at $1.28 \mathrm{~V}$. Therefore, the involvement of the buffer base in PCET pathway directly contributes to the enhanced catalytic activity, which is associated with the electron transferring to electrode occurring along with proton transfer to the added base. CVs were also recorded with different catalyst concentrations at $\mathrm{pH}$ 7.0. As the concentration varies from $0.2 \mathrm{mM}$ to $1.0 \mathrm{mM}$, a sharp enhancement of catalytic current for water oxidation was obtained (Supplementary Fig. 32).

Electrochemistry under neutral conditions. Accordingly, electrochemical behaviors of $1.0 \mathrm{mM} \mathbf{R u}$-bds and Ru-bda were further explored in $0.20 \mathrm{M} \mathrm{pH} 7.0$ phosphate buffer solutions (Fig. 8 and Supplementary Fig. 33). To our delight, Ru-bds exhibited an ultra-high electrocatalytic current density of $11.79 \mathrm{~mA} \mathrm{~cm}^{-2}$ (at $1.63 \mathrm{~V}$ with scan rate of $0.1 \mathrm{mV} \mathrm{s}^{-1}$, Fig. 8) with a low onset overpotential of $380 \mathrm{mV}$. In comparison, the current density of Ru-bda is only $3.26 \mathrm{~mA} \mathrm{~cm}^{-2}$ (at $1.63 \mathrm{~V}$ with scan rate of $0.1 \mathrm{mV}$ $\mathrm{s}^{-1}$, Fig. 8). This significant current density enhancement by Rubds highlights the importance of PCET in avoiding the high energy barrier for the electrochemical water oxidation. To the best of our knowledge, such a value of the catalytic current density is among the highest ever reported in the literature under neutral conditions for $\mathrm{Ru}-$ WOCs catalysed water oxidation (Supplementary Table 3) 29,30,43,44. Under the steady-state conditions, a TOF of $12900 \mathrm{~s}^{-1}$ was achieved by Ru-bds at the scan rate of $1.3 \mathrm{~V} \mathrm{~s}^{-1}$ (Fig. 9a) while Ru-bda displayed a TOF of $300 \mathrm{~s}^{-1}$ at the scan rate of $2.0 \mathrm{~V} \mathrm{~s}^{-1}$. The latter is about two orders of magnitude smaller than that of Ru-bds (Fig. 9b). Bulk electrolysis of $\mathbf{R u}$-bds in $\mathrm{pH} 7.0$ for $2 \mathrm{~h}$ displays a decay with $30 \%$ retention of the initial current density (Supplementary Fig. 34a) while the Faradaic efficiency was determined to be $94 \%$. The CVs (Supplementary Fig. 35) show that the $\mathrm{Ru}^{\mathrm{III} / \mathrm{II}}$ peak current retains after bulk electrolysis while the catalytic current density of $8.2 \mathrm{~mA} \mathrm{~cm}^{-2}$ only decays to $6.8 \mathrm{~mA} \mathrm{~cm}^{-2}$. The two signals of $\left[\mathrm{Ru}^{\mathrm{II}}\left(\mathrm{bds}^{2-}\right)(\mathrm{pic})_{2}+\mathrm{Na}\right]^{+}$and $\left[\mathrm{Ru}^{\mathrm{II}}\left(\mathrm{bdsNa}{ }^{-}\right)(\text {pic })_{2}\left(\mathrm{CH}_{3} \mathrm{CN}\right)\right]^{+}$ are still the dominate species without formation of new $\mathrm{Ru}$ species (Supplementary Figs. 36 and 37).

In our previous study, the mixed-valence $\mathrm{Ru}$ trimer species for Ru-bda-catalyzed water oxidation under neutral conditions were proved by using chemical and electrochemical methods and have been successfully isolated and characterized ${ }^{45}$. Herein, the spectroelectrochemistry of Ru-bds was examined at a constant potential of $1.21 \mathrm{~V}$, where the absorption changes of the electrolysis solution were in situ monitored by UV-Vis spectroscopy. As shown in Supplementary Fig. 38, no observable band at $690 \mathrm{~nm}$ was observed where the band at $690 \mathrm{~nm}$ is a typical absorption peak of the trinuclear $\mathrm{Ru}$ species. Therefore, there is no $\mu$-oxo oligomeric species formed in the case of Ru-bds. More importantly, the electrode surfaces before and after electrolysis have also been characterized by scanning electron microscopy (SEM) and energydispersive X-ray spectroscopy (EDX) (Supplementary Fig. 39). No $\mathrm{Ru}$ elements and species was deposited on the electrode surface, ruling out the potential catalyst decomposition into the $\mathrm{RuO}_{2}$.

As shown in the Pourbaix diagram, a $\mathrm{pH}$ independent oxidation process at $1.0 \mathrm{~V}$ appears at $\mathrm{pH}>5.5$ (grey stars in Supplementary Fig. 15), and this oxidation wave is relatively small compared with the $\mathrm{Ru}^{\mathrm{III} / \mathrm{II}}$ wave (Supplementary Fig. 33). The $\mathrm{Ru}^{\mathrm{III} / \mathrm{II}}$ and $\mathrm{Ru}^{\mathrm{IV} / \mathrm{III}}$ data points respectively aligned well in the whole $\mathrm{pH}$ range. Thereby, we propose that the $\mathrm{pH}$ independent oxidation process at $1.0 \mathrm{~V}$ belongs to a decomposed/evolved $\mathrm{Ru}$ species whose structure is currently unknown. Given that, the oxidation of $\mathrm{Ru}^{\mathrm{III}}-\mathrm{OH}$ to $\mathrm{Ru}^{\mathrm{IV}}=\mathrm{O}$ triggers water oxidation with $E_{\text {onset }}=1.2 \mathrm{~V}$ at $\mathrm{pH} 7.0$. 


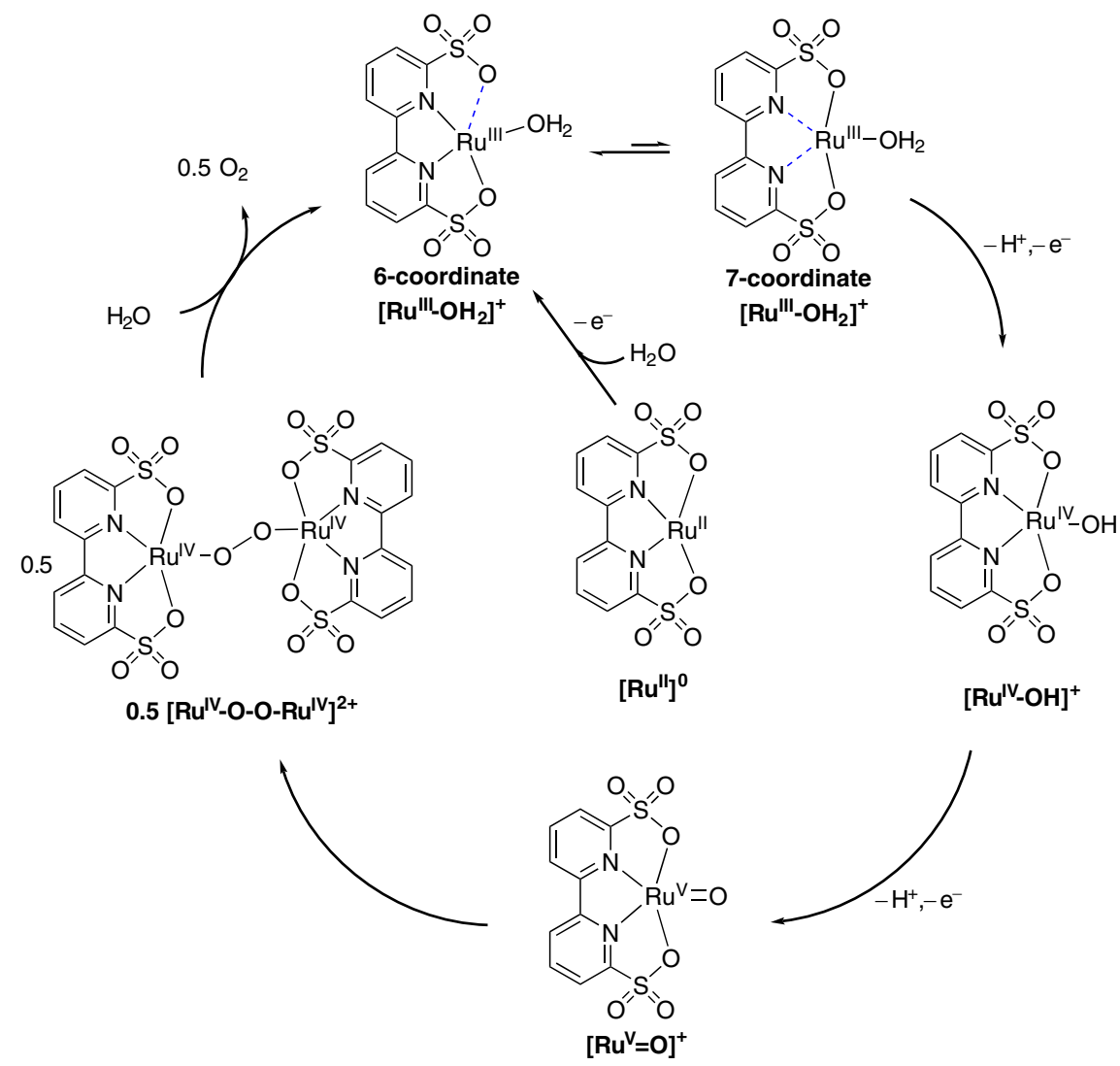

Fig. 7 Proposed mechanism. Proposed electrochemical driven water oxidation and O-O bond formation pathway by Ru-bds under the acidic conditions.

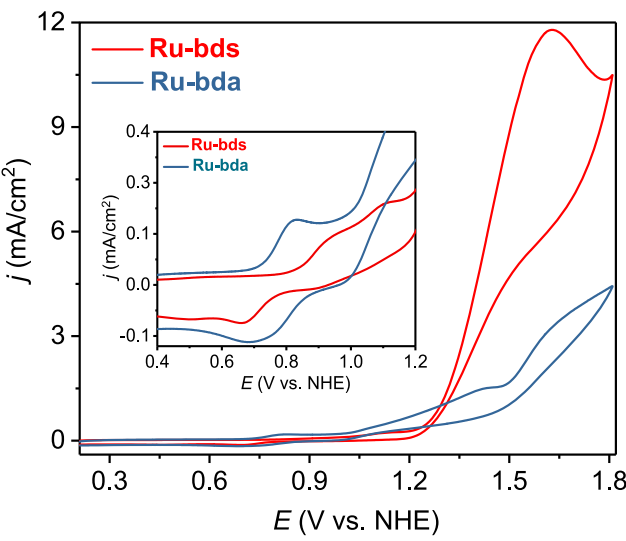

Fig. 8 Electrochemical behavior under neutral conditions. CVs of $1.0 \mathrm{mM}$ Ru-bda and Ru-bds in pH 7.0 phosphate buffer containing $20 \%$ volume $\mathrm{CH}_{3} \mathrm{CN}$ with scan rate of $100 \mathrm{mV} \mathrm{s}^{-1}[0.2 \mathrm{M}$ phosphate buffer, $\mathrm{I}=0.5 \mathrm{M}$ $\left(\mathrm{NaNO}_{3}\right)$ ], the diameter of glassy carbon working electrode is $3 \mathrm{~mm}$. Inset: Enlargement of the $0.4-1.2 \mathrm{~V}$ zone in the CV.

Density functional theory calculations at $\mathbf{p H}$ 7.0. DFT calculations were also performed to gain more insight in the reaction mechanism by $\mathbf{R u}$-bds at $\mathrm{pH}$ 7.0. From the Pourbaix diagram, the $\mathrm{Ru}^{\mathrm{III}}-\mathrm{OH}$ will form the $\mathrm{Ru}^{\mathrm{IV}}=\mathrm{O}$ species at $\mathrm{pH}>$ 4.6. Calculations showed that the Gibbs free energy of $\left[\mathrm{Ru}^{\mathrm{III}}-\mathrm{OH}\right]^{+}{ }_{(6 \text {-coordinate })}$ is only $0.8 \mathrm{kcal} \mathrm{mol}^{-1}$ lower than that of the $\left[\mathrm{Ru}^{\mathrm{III}}-\mathrm{OH}\right]^{+}{ }_{(7 \text {-coordinate) }}$ In the phosphate buffer, $\left[\mathrm{Ru}^{\mathrm{IV}}-\mathrm{OH}\right]^{+}$is deprotonated by $\mathrm{H}_{2} \mathrm{PO}_{4}{ }^{-}$(dominate species in $\mathrm{pH} 7.0$ phosphate buffer), forming the $\mathrm{Ru}^{\mathrm{IV}}=\mathrm{O}$ (Supplementary Fig. 40) species. Since the Gibbs free energy of $\mathrm{Ru}^{\mathrm{IV}}=\mathrm{O}$ at triplet state is $16.6 \mathrm{kcal} \mathrm{mol}^{-1}$ lower than that of singlet geometry, we used triplet state of the $\mathrm{Ru}^{\mathrm{IV}}=\mathrm{O}$ species for the calculations. The calculated redox potential of $\left[\mathrm{Ru}^{\mathrm{III}}-\mathrm{OH}\right]^{+}{ }_{(7-\text { coordinate })} /\left[\mathrm{Ru}^{\mathrm{I}}\right.$ $\mathrm{V}=\mathrm{O}]_{\mathrm{T}}$ is $1.08 \mathrm{~V}$ at $\mathrm{pH}$ 7.0. When the $\mathrm{Ru}^{\mathrm{IV}}=\mathrm{O}$ species form the $\mathrm{O}$ $-\mathrm{O}$ bond via the WNA pathway using $\mathrm{H}_{2} \mathrm{PO}_{4}^{-}$(a stronger base than water) as a proton acceptor, (i) at the triplet state the activation free energy is $51.3 \mathrm{kcal} \mathrm{mol}^{-1}$ and the reaction free energy is $33.9 \mathrm{kcal} \mathrm{mol}^{-1}$ (Fig. 10a), and (ii) at the singlet state the activation free energy is $19.8 \mathrm{kcal} \mathrm{mol}^{-1}$ and the reaction free energy is $15.0 \mathrm{kcal} \mathrm{mol}^{-1}$. Therefore the total activation free energy of WNA pathway is $36.4 \mathrm{kcal} \mathrm{mol}^{-1}$ and the reaction free energy is $31.6 \mathrm{kcal} \mathrm{mol}^{-1}$ (the energy profile at singlet plus the energy difference of $16.6 \mathrm{kcal} \mathrm{mol}^{-1}$ between the singlet and triplet of $\mathrm{Ru}^{\mathrm{IV}}=\mathrm{O}$ species; Fig. 10b).

We have also calculated transition state of radical coupling of two $\mathrm{Ru}^{\mathrm{IV}}=\mathrm{O}$ species by scanning the terminal $\mathrm{O}-\mathrm{O}$ bond distance $\left[\mathrm{Ru}^{\mathrm{IV}}=\mathrm{O} \cdots \mathrm{O}=\mathrm{Ru}^{\mathrm{IV}}\right]$ of the antiferromagnetic openshell singlet, giving an activation free energy of $6.1 \mathrm{kcal} \mathrm{mol}^{-1}$ from the pre-reactive dimer to the transition state, and a reaction free energy of $1.1 \mathrm{kcal} \mathrm{mol}^{-1}$ (Fig. 10c). We have also parameterized $\mathrm{Ru}^{\mathrm{IV}}=\mathrm{O}_{\mathrm{T}}$ and tested stability by molecular dynamics (MD; Supplementary Fig. 26). The two neutral $\mathrm{Ru}^{\mathrm{IV}}=\mathrm{O}_{\mathrm{T}}$ species are more prone to form the prereactive complex with a lower binding free energy of $-5 \mathrm{kcal} \mathrm{mol}^{-1}$ (Supplementary Fig. 28), compared to the two $\left[\mathrm{Ru}^{\mathrm{V}}=\mathrm{O}\right]^{+}$species. Therefore the overall activation energy of the $\mathrm{O}-\mathrm{O}$ bond formation from two separated $\mathrm{Ru}^{\mathrm{IV}}=\mathrm{O}_{\mathrm{T}}$ complexes is only $1.1 \mathrm{kcal} \mathrm{mol}^{-1}$. Further oxidation of $\left[\mathrm{Ru}^{\mathrm{IV}}=\mathrm{O}\right]_{\mathrm{T}}$ to form the $\left[\mathrm{Ru}^{\mathrm{V}}=\mathrm{O}\right]^{+}$however has an oxidation potential of $1.89 \mathrm{~V}$. The high oxidation potential of $\mathrm{Ru}^{\mathrm{V} / \mathrm{IV}}$ and the high activation free energy of the WNA pathway indicates that under neutral conditions the $\mathrm{O}-\mathrm{O}$ bond formation would occur via the I2M pathway at the $\mathrm{Ru}^{\mathrm{IV}}=\mathrm{O}$ state; the I2M pathway at the $\mathrm{Ru}^{\mathrm{IV}}=\mathrm{O}$ state is a new discovery for the molecular based water oxidation catalysis while Meyer and coworkers have 

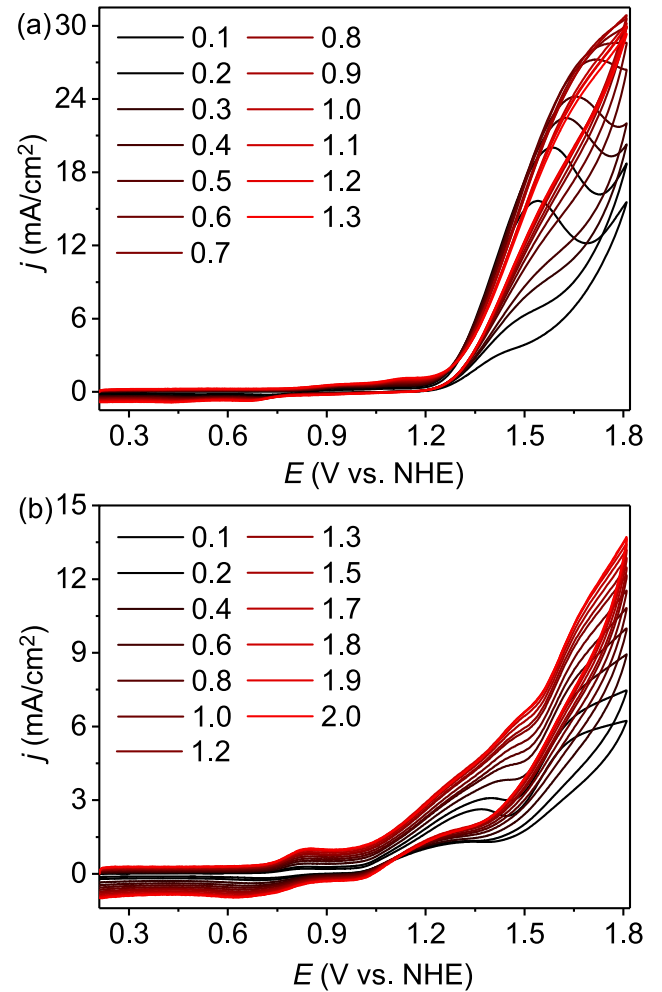

Fig. 9 Electrochemistry under neutral conditions. a CVs of Ru-bds in $\mathrm{pH}$ 7.0 phosphate buffer containing $20 \% \mathrm{CH}_{3} \mathrm{CN}$ at different scan rates from 0.1 to $1.3 \mathrm{~V} \mathrm{~s}^{-1}$. b CVs of Ru-bda in $\mathrm{pH} 7.0 / \mathrm{CH}_{3} \mathrm{CN}$ at different scan rates from 0.1 to $2.0 \mathrm{~V} \mathrm{~s}^{-1}$. Conditions: $0.2 \mathrm{M}$ phosphate buffer, I $=0.5 \mathrm{M}$ $\left(\mathrm{NaNO}_{3}\right)$, glassy carbon working electrode $(\Phi 3 \mathrm{~mm})$. Note: $i_{\text {cat }}$ values at $1.70 \vee$ were used to calculate the TOF for both Ru-bds and Ru-bda.

reported a $\mathrm{Ru}^{\mathrm{IV}}=\mathrm{O}$ catalyzed WNA pathway ${ }^{46}$. Taking the electrochemistry results and theoretical calculations into account, we propose that the rate-limiting step in electrochemical water oxidation by $\mathbf{R u}$-bds at $\mathrm{pH} 7.0$ is the oxidation of $\mathrm{Ru}^{\mathrm{III}}-\mathrm{OH}$ to $\mathrm{Ru}^{\mathrm{IV}}=\mathrm{O}$, and the $\mathrm{O}-\mathrm{O}$ bond forms via the radical coupling of two $\mathrm{Ru}^{\mathrm{IV}}=\mathrm{O}$ species.

In summary, by introducing two sulfonate groups into a bipyridine ligand, a mononuclear $\mathrm{Ru}$ catalyst Ru-bds was developed for effective electrocatalytic water oxidation with TOF of $160 \mathrm{~s}^{-1}$ under acidic conditions while outstanding catalytic activity with a high TOF of $12900 \mathrm{~s}^{-1}$ was successfully obtained under neutral conditions. The bds ${ }^{2-}$ ligand, with the proper electron-donating ability and suitable ligation sites, plays a vital role on stabilizing high valent $\mathrm{Ru}$ states, adapting the 7coordination configuration of reaction intermediates and promoting the $\mathrm{O}-\mathrm{O}$ bond formation via the I2M mechanism. DFT calculations revealed that the radical coupling of two $\mathrm{Ru}^{\mathrm{IV}}=\mathrm{O}$ species at neutral conditions proceeds with a low activation barrier of $1.1 \mathrm{kcal} \mathrm{mol}^{-1}$, providing a new insight in water oxidation mechanism catalyzed by Ru-based water oxidation catalysts under neutral conditions. In particular, this work illuminates the impact of structural changes on the electrochemical catalytic activity and further provides an inspiring strategy to design more efficient and robust WOCs for potential applications in electrocatalysis and photoelectrocatalysis.

\section{Methods}

Physical measurements and instrumentation. Nuclear magnetic resonance (NMR) spectra were obtained with $400 \mathrm{MHz}$ of Bruker Advance spectrometer. Elemental analyses were performed with an Elementar Vario EL elemental analyzer. Mass spectrometry measurements were carried out by a Thermo Scientific (a)
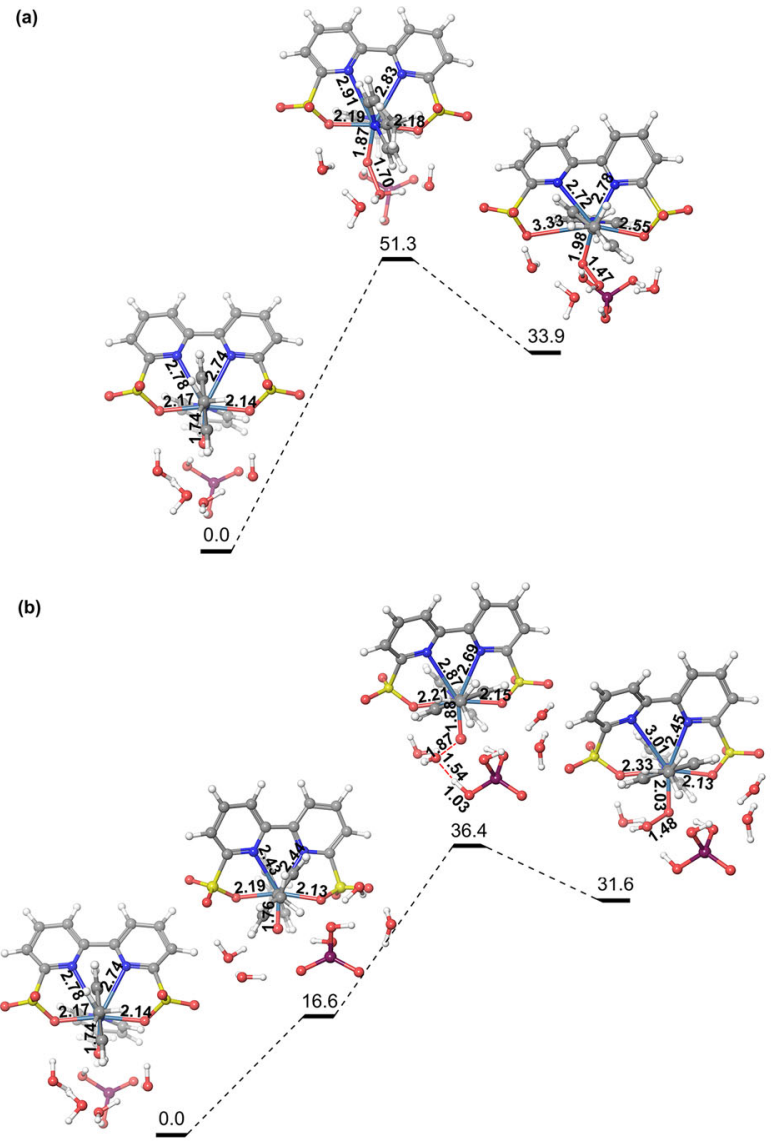

(c)
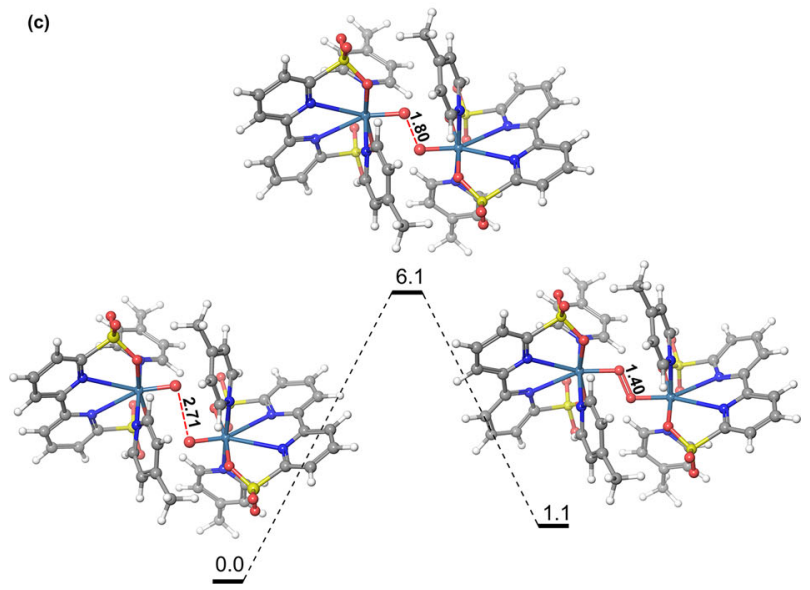

Fig. 10 DFT calculated energy profiles. The energy profiles of $\mathrm{O}-\mathrm{O}$ bond formation of $\mathrm{Ru}^{\mathrm{IV}}=\mathrm{O}$ at $\mathrm{pH} 7.0$ with the a WNA of triplet $\mathrm{Ru}^{\mathrm{IV}}=\mathrm{O}$ using $\mathrm{H}_{2} \mathrm{PO}_{4}{ }^{-}$as base, $\boldsymbol{b}$ WNA of singlet $\mathrm{Ru}^{\mathrm{IV}}=\mathrm{O}$ using $\mathrm{H}_{2} \mathrm{PO}_{4}{ }^{-}$as base, and c $12 \mathrm{M}$ mechanism. The units of energies are kcal mol${ }^{-1}$.

LCQ Fleet mass spectrometer. High-resolution mass spectrometry measurements were performed on a Thermo Scientific Q Exactive mass spectrometer. Electrochemistry measurements were performed with a CHI760 electrochemical workstation. For cyclic voltammetry and differential pulse voltammetry measurements, a glassy carbon disk (diameter $3 \mathrm{~mm}$ ) was used as the working electrode and a platinum column as the counter electrode, and measured versus $\mathrm{Ag} / \mathrm{AgCl}$ reference electrode ( $3 \mathrm{M} \mathrm{KCl} ; 210 \mathrm{mV}$ vs. $\mathrm{NHE}$ ) in aqueous solutions (conditions: [cat] = $1.0 \mathrm{mM}$; $\mathrm{pH} 1.0$ triflic acid or $\mathrm{pH} 7.0,0.2 \mathrm{M}$ phosphate buffer, $\mathrm{I}=0.5 \mathrm{M}\left(\mathrm{NaNO}_{3}\right)$ ). For bulk electrolysis, the working electrode was a glassy carbon piece $\left(2.86 \mathrm{~cm}^{2}\right)$, the counter electrode a platinum wire and the reference electrode a saturated $\mathrm{Ag} /$ $\mathrm{AgCl}$ electrode $(3 \mathrm{M} \mathrm{KCl})$. Typically, $7 \mathrm{~mL}$ of $0.5 \mathrm{mM} \mathrm{Ru}$-bds in $\mathrm{CH}_{3} \mathrm{CN} / \mathrm{pH} 1.0$ or $\mathrm{pH} 7.0(0.2 \mathrm{M}$ phosphate buffer) solutions $(1 / 4, \mathrm{v} / \mathrm{v})$ was prepared and the electrolysis current was recorded with an applied potential of $1.7 \mathrm{~V}$ at $\mathrm{pH} 1.0$ or $1.5 \mathrm{~V}$ at $\mathrm{pH}$ 7.0. The electrolytic oxygen evolution in a standard three-electrode $\mathrm{H}$-cell 
configuration was monitored by GC9790Plus. The $\mathrm{Ce}^{\mathrm{IV}}$-driven oxygen was detected by a pressure transducer (MIK-P300) driven at $10.00 \mathrm{~V}$ using a power supply (HY3005B) plus a data acquisition module (Omega OM-DAQ-USB-2401). The single crystal X-ray diffraction data were collected at $298 \mathrm{~K}$ on a Bruker SMART CCD $1 \mathrm{~K}$ diffractometer with a graphite-monochromated Mo- $K_{\alpha}$ radiation $(\lambda=0.71073 \AA)$. The structure was solved and refined using the Olex 2 program ${ }^{47}$. Small fraction of twinning domains was suspected in the present datasets. To understand the twining problem, the twin rotation law has been carefully studied with the Platon software (A.L.Spek, Acta Cryst. 2020, E76, 1-11). The twin law of

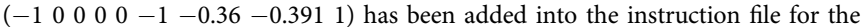
final refinement. The final refinement has been successfully lower down the refinement R1 value from $8.05 \%$ to $6.71 \%$ with improved residue electron density. A twining fraction of $4.5 \%$ as founded based on the refinement results. The spectroelectrochemistry was carried out in a Y-shaped quartz cuvette equipped with $\mathrm{Pt}$ mesh as working electrode, a Pt wire as counter electrode and an $\mathrm{Ag} / \mathrm{AgCl}$ reference electrode. The quartz cuvette was filled with $1 \mathrm{~mL} 0.5 \mathrm{mM}$ Ru-bds in phosphate buffer solution ( $\mathrm{pH} 7,0.2 \mathrm{M}, 20 \% \mathrm{CH}_{3} \mathrm{CN}$ ). The path length of the Y-shaped quartz cuvette is $1.0 \mathrm{mM}$. UV-vis absorption spectra were obtained by Agilent Technologies Cary 8454. The morphologies of electrode surfaces before and after electrolysis were characterized by a JSM-7500F field emission scanning electron microscopy (SEM, JEOL, Japan).

Synthesis of 2,2'-bipyridine-6,6'-disulfonic acid. To a solution of 6,6'-dibromo$2,2^{\prime}$-bipyridine $(312 \mathrm{mg}, 1.0 \mathrm{mmol})$ in dry DMF $(8 \mathrm{~mL})$, ten equivalents of sodium hydrosulfide $(560 \mathrm{mg}, 10 \mathrm{mmol})$ were added. The reaction mixture was heated under $180^{\circ} \mathrm{C}$ for $2 \mathrm{~h}$ using Microwave reactor. The resultant orange mixture was dried under vacuum. Dissolve the residue in distilled water, and $\mathrm{CH}_{3} \mathrm{COOH}$ was added drop wised until the precipitation stopped. The precipitate was filtrated and washed by distilled water, finally dried under vacuum. The product of $6,6^{\prime}$-dithiol$2,2^{\prime}$-bipyridine was afforded as an orange powder $(167 \mathrm{mg}, 76 \%$ yield; its $1 \mathrm{D}$ and 2D NMR spectra were recorded to characterize this compound, as shown in Supplementary Figs. 1-2; ${ }^{1} \mathrm{H}$ NMR (400 MHz, $d_{6}$-DMSO) $\delta 13.67$ (s, 2H), 7.47 (dd, $J=8.5,7.3 \mathrm{~Hz}, 2 \mathrm{H}), 7.36(\mathrm{dd}, J=8.7,0.9 \mathrm{~Hz}, 2 \mathrm{H}), 7.03(\mathrm{~d}, J=6.3 \mathrm{~Hz}, 2 \mathrm{H})$. HRMS: $\mathrm{m} / \mathrm{z}^{-}=219.0051\left(\mathrm{M}-\mathrm{H}^{+}\right)$; calcd, 219.0056.), and used for the next step synthesis without further purification. Compound 6,6'-dithiol-2,2'-bipyridine $(100 \mathrm{mg})$ was dissolved in $8 \mathrm{~mL}$ nitric acid $(70 \%$, purified by redistillation, $\geq 99.999 \%$ trace metals basis), and the solution was heated at $100{ }^{\circ} \mathrm{C}$ for $2 \mathrm{~h}$, and then the acid was removed by vacuum. The product of $2,2^{\prime}$-bipyridine- $6,6^{\prime}$-disulfonic acid $\left(\mathrm{bdsH}_{2}\right)$ was obtained as pale yellow powder in a quantitative yield. Its $1 \mathrm{D}$ and 2D NMR spectra were recorded (Supplementary Figs. 3-5). ${ }^{1} \mathrm{H}$ NMR $\left(400 \mathrm{MHz}, \mathrm{D}_{2} \mathrm{O}\right) \delta 8.50(\mathrm{dd}, J=8.0,0.8 \mathrm{~Hz}, 2 \mathrm{H}), 8.20(\mathrm{t}, J=7.9 \mathrm{~Hz}, 2 \mathrm{H}), 8.02(\mathrm{dd}$, $J=7.8,0.7 \mathrm{~Hz}, 2 \mathrm{H}) .{ }^{13} \mathrm{C}$ NMR $\left(101 \mathrm{MHz}, \mathrm{D}_{2} \mathrm{O}\right) \delta 161.50,157.37,143.05,127.28$, 124.18. HRMS: $\mathrm{m} / \mathrm{z}^{-}=314.9750\left(\mathrm{M}-\mathrm{H}^{+}\right)$; calcd, 315.9751. Calcd. for $\mathrm{bdsH}_{2}$ $\left(\mathrm{C}_{10} \mathrm{H}_{8} \mathrm{~N}_{2} \mathrm{O}_{6} \mathrm{~S}_{2}\right)$ : C 35.93; H 2.55; N 8.86. Found: C 35.81; H 2.99; N 8.83.

Synthesis of [Ru(bds)(pic) $\left.)_{2}\right]$. To a solution of 2,2' -bipyridine-6,6'-disulfonic acid $(100 \mathrm{mg}, 0.32 \mathrm{mmol})$ in dry $\mathrm{MeOH}(5 \mathrm{~mL})$, dichloro(p-cymene)ruthenium(II) dimer ( $98 \mathrm{mg}, 0.16 \mathrm{mmol}$ ), ten equivalents of 4-picoline and ten equivalents of $\mathrm{Et}_{3} \mathrm{~N}$ were added. The resulting mixture was then heated under $125^{\circ} \mathrm{C}$ for 40 min using a microwave reactor. The solvent was removed by vacuum, and the crude product purified by column chromatography. The target complex was afforded as a dark red powder $(65 \mathrm{mg}, 35 \%$ yield). The 1D and 2D NMR spectra (Supplementary Figs. 6-8) were recorded to characterize the complex. ${ }^{1} \mathrm{H}$ NMR $\left(400 \mathrm{MHz}\right.$, mixed $\mathrm{CD}_{3} \mathrm{OD}$ and $\left.\mathrm{CD}_{2} \mathrm{Cl}_{2}\right): \delta 8.46(\mathrm{~d}, J=8.1 \mathrm{~Hz}, 2 \mathrm{H}), 8.09(\mathrm{~d}, J=7.5 \mathrm{~Hz}, 2 \mathrm{H}), 7.96(\mathrm{t}, J=8.0 \mathrm{~Hz}, 2 \mathrm{H})$, $7.82(\mathrm{~d}, J=6.6 \mathrm{~Hz}, 4 \mathrm{H}), 7.03(\mathrm{dd}, J=6.6,0.6 \mathrm{~Hz}, 4 \mathrm{H}), 2.31(\mathrm{~s}, 6 \mathrm{H}) .{ }^{13} \mathrm{C}$ NMR $(101$ MHz, $d_{6}$-DMSO) $\delta 163.56,159.57,151.11,148.83,133.94,126.01,125.74,122.68$, 20.23. HRMS: calcd for $602.9973\left(\mathrm{M}+\mathrm{H}^{+}\right)$; found $\mathrm{m} / \mathrm{z}^{+}=602.9940$. Anal. Calcd for $\left[\mathrm{Ru}(\mathrm{bds})(\mathrm{pic})_{2}\right]\left(\mathrm{C}_{22} \mathrm{H}_{20} \mathrm{~N}_{4} \mathrm{O}_{6} \mathrm{RuS}_{2}\right)$ : Calcd. C 43.92; H 3.35; N 9.31. Found: C 43.86; $\mathrm{H}$ 3.52; N 9.38. Single crystals of Ru-bds was obtained by diffusing diethyl ether into $\mathrm{CH}_{3} \mathrm{OH} / \mathrm{CH}_{2} \mathrm{Cl}_{2}(1 / 5, \mathrm{v} / \mathrm{v})$ solution of complex Ru-bds.

Computational details. All DFT calculations for the estimation of Gibbs free energies were carried out with the Jaguar 8.3 program package by Schrödinger $\mathrm{LLC}^{48}$. Molecular geometries were optimized using Becke's three-parameter hybrid functional and the LYP correlation functional (B3LYP) ${ }^{49}$ with D3 correction of Grimme et $\mathrm{al}^{50,51}$. with the LACVP** basis set ${ }^{52}$. Single-point energy corrections were performed with the B3LYP-D3 functional using the LACVP** ++ basis set augmented with two f-functions on the metal. Frequency calculations were performed on the optimized geometries to verify that the geometries correspond to minima on the potential energy surface (PES). On the basis of the gas-phase optimized geometries, the solvation energies were estimated by single-point calculations using the Poisson-Boltzmann reactive field implemented in Jaguar (PBF) in water. To identify the transition states for $\mathrm{O}-\mathrm{O}$ bond formation of I2M mechanism, we searched the potential energy surface by scanning the terminal $\mathrm{O}-\mathrm{O}$ bond distance $\left[\mathrm{Ru}^{\mathrm{V}}=\mathrm{O} \cdots \mathrm{O}=\mathrm{Ru}^{\mathrm{V}}\right]^{2+}$ and $\left[\mathrm{Ru}^{\mathrm{IV}}=\mathrm{O} \cdots \mathrm{O}=\mathrm{Ru}^{\mathrm{IV}}\right]$ of the antiferromagnetic open shell singlet. The Gibbs free energy were defined as the following equation $G=E($ B3LYP-D3/LACVP** $++2 \mathrm{f}$ on $\mathrm{Ru})+\mathrm{G}_{\text {solv }}+\mathrm{ZPE}+$ $H_{298}-T S_{298}+1.9 \mathrm{kcal} / \mathrm{mol}$ (the value $1.9 \mathrm{kcal} / \mathrm{mol}$ is a concentration correction to the free energy of solvation, which by default is calculated at $1 \mathrm{M}(\mathrm{g})$ to $1 \mathrm{M}(\mathrm{aq})$ in Jaguar). Four additional water molecules were included in the calculation.

Force field parameterization. With the optimized geometries of $\left[\mathrm{Ru}^{\mathrm{V}}=\mathrm{O}\right]^{+}$and $\mathrm{Ru}^{\mathrm{IV}}=\mathrm{O}_{\mathrm{T}}$, equilibrium bonds, angles, and dihedrals were obtained. Then a series of relaxed coordinate scans were performed by DFT calculations from the equilibrium bonds, angles, and dihedrals to get the force field parameters. Each bond was stretched $0.3 \AA$ in each direction for a total scan span of $0.6 \AA$, and each angle was stretched $15^{\circ}$ in each direction for a total scan span of $30^{\circ}$. The scans were made in 15 increments each way. The scans were fitted to a second-degree polynomial as the following equation where the square term coefficient, $k_{b}$, is the force constant.

$$
K_{b}\left(r-r_{0}\right)^{2}=K_{b} r^{2}-2 K_{b} r r_{0}+K_{b} r_{0}^{2}
$$

The angle parameters have also been plotted with the force constants $v s$ equilibrium angle. Because of the fairly planar structure, most of the dihedral angles have been ignored i.e $K_{\psi}=0$, but the dihedral angles that rotates the axial ligand $\mathrm{Ru}-\mathrm{N}$ bonds have been scanned with the DFT method, and crudely fitted with one cosine series in order to capture the barrier height and equilibrium angles.

Electrostatic potential (ESP) charges were calculated using the DFT method for $\left[\mathrm{Ru}^{\mathrm{V}}=\mathrm{O}\right]^{+}$(total charge $\left.=+1\right)$ and $\mathrm{Ru}^{\mathrm{IV}}=\mathrm{O}_{\mathrm{T}}$ (total charge $\left.=0\right)$. As an improvement on performing only a single ESP charge calculation, a chargeaveraging scheme was implemented, which was performed as follows: 1) Initial ESP charges were calculated at the starting geometry. 2) An MD simulation (gas phase, $300 \mathrm{~K}$, step size $1 \mathrm{fs}$ ) was performed starting with the initial structure and charges. A harmonic restraint of $5.0 \mathrm{kcal} \mathrm{mol}^{-1}$ was added to Ru atom to restrain it from moving too far from its initial position while the other atoms could move freely during $100 \mathrm{ps}$ of simulation time. A snapshot was extracted every $10 \mathrm{ps}$ of this simulation, at which point new ESP charges were calculated. 3) The procedure was repeated three times, but with the exception that the initial charges of the second and third runs were taken as the average of the ESP charges from the previous run. Each time this procedure was repeated, the charges became more stable, and the procedure was stopped on the third round, when the charges had converged (small standard deviations between the partial charges of the different conformations). All van der Waals parameters used in this work are from the work of Bernardes et. $a .^{53}$, where the vdW parameters were determined for $\mathrm{M}(\mathrm{CO})_{\mathrm{n}}$ structures for a number for transition metals.

Since $\left[\mathrm{Ru}^{\mathrm{V}}=\mathrm{O}\right]^{+}$and $\mathrm{Ru}^{\mathrm{IV}}=\mathrm{O}_{\mathrm{T}}$ have the close to identical geometries with different oxidation states, we use same vdW parameters, bond stretch parameters angle bend parameters, torsion parameters and improper torsion parameters for these two complexes with different calculated average electrostatic potential charges. In order to run $\mathrm{MD}$ simulations, the parameters were then transformed into the Gromacs topology format, where the Fourier coefficients of the dihedral potential term were transformed into the Ryckaerd-Bellemans type ${ }^{54}$.

Molecular dynamics simulations. For two MD simulations, the catalyst was sequentially equilibrated in the following order: 1) A 10 ps simulation at $1 \mathrm{~K}$, applying a $5.0 \mathrm{kcal} \mathrm{mol}^{-1}$ harmonic restraint on each atom to restraint them to their DFT optimized geometries, and using a 0.1 fs stepsize. 2) A 100 ps simulation at $100 \mathrm{~K}$, applying a $5.0 \mathrm{kcal} \mathrm{mol}^{-1}$ harmonic restraint on each atom and increasing to a $1 \mathrm{fs}$ step size. 3) A final $1 \mathrm{~ns}$ equilibration at $300 \mathrm{~K}$, reducing the overall harmonic restraint on each atom to $1 \mathrm{kcal} \mathrm{mol}^{-1}$ and remaining the stepsize of $1 \mathrm{fs}$. Solvent was included in the simulations using a $20 \AA$ radius sphere of explicit TIP3P water molecules centered on the centroid of the reacting atoms. The sphere was described as a multi-level system in which the inner $85 \%$ of the sphere was allowed to move freely, but all atoms in the last $25 \%$ of the sphere were subjected to a $10 \mathrm{kcal} \mathrm{mol}^{-1} \AA^{-2}$ to maintain system stability, as is routine when using the Surface Constrained All Atom Solvent (SCAAS) model ${ }^{55,56}$.

Potential of mean force. PMF were performed for the Ru-Ru distance of two complexes in water phase using umbrella sampling method with the Gromacs 5.1.4 MD software package ${ }^{57}$. Equilibrations were performed for 100 ps under an NVT ensemble, using the same methodology described in previous report ${ }^{39}$. The two Ru complexes were pulled apart for total $10 \AA$ from the core structure over $200 \mathrm{ps,}$ using a spring constant of $30 \mathrm{~kJ} \mathrm{~mol}^{-1} \AA^{-2}$ and a pull rate of $0.05 \AA \mathrm{ps}^{-1}$. From these trajectories, snapshots were taken to generate the starting configurations for the umbrella sampling windows. Then we sampled the distances using roughly $0.5 \AA$ spacing. Such spacing allowed for increasing detail at smaller Ru-Ru distance and resulted in 21 windows. In each window, $20 \mathrm{~ns}$ of MD was performed for a total simulation time of $420 \mathrm{~ns}$ utilized for umbrella sampling. Analysis of results was performed with the weighted histogram analysis method (WHAM) ${ }^{58}$. All PMF simulations resulted in smooth dissociation curves and the mean value from three repeated simulations.

\section{Data availability}

All data needed to evaluate the conclusions of this paper are present in the paper and/or Supplementary Information. The source data underlying Supplementary Figs. 26-29 are provided as a Source Data file. The data that support the findings of this study are available from the corresponding author upon request. The X-ray crystallographic data of Ru-bds reported in this study has been deposited at the Cambridge Crystallographic 
Data Center (CCDC), under deposition numbers 1899698 [https://doi.org/10.5517/ccdc. csd.cc21rs16]. The data can be obtained free of charge from The Cambridge Crystallographic Data Center via http://www.ccdc.cam.ac.uk/ data_request/cif. Source data are provided with this paper.

Received: 15 February 2020; Accepted: 14 December 2020; Published online: 14 January 2021

\section{References}

1. Berardi, S. et al. Molecular artificial photosynthesis. Chem. Soc. Rev. $\mathbf{4 3}$, 7501-7519 (2014).

2. Diaz-Morales, O. et al. Iridium-based double perovskites for efficient water oxidation in acid media. Nat. Commun. 7, 12363 (2016).

3. Feng, J. R. et al. Iridium-based multimetallic porous hollow nanocrystals for efficient overall-water-splitting catalysis. Adv. Mater. 29, 1703798 (2017).

4. Mondschein, J. S. et al. Crystalline cobalt oxide films for sustained electrocatalytic oxygen evolution under strongly acidic conditions. Chem. Mater. 29, 950-957 (2017).

5. Hu, F. et al. Amorphous metallic NiFeP: a conductive bulk material achieving high activity for oxygen evolution reaction in both alkaline and acidic media. Adv. Mater. 29, 1606570 (2017).

6. Huynh, M., Bediako, D. K. \& Nocera, D. G. A functionally stable manganese oxide oxygen evolution catalyst in acid. J. Am. Chem. Soc. 136, 6002-6010 (2014).

7. Fillol, J. L. et al. Efficient water oxidation catalysts based on readily available iron coordination complexes. Nat. Chem. 3, 807-813 (2011).

8. Wickramasinghe, L. D. et al. Iron complexes of square planar tetradentate polypyridyl-type ligands as catalysts for water oxidation. J. Am. Chem. Soc. 137, 13260-13263 (2015).

9. Kottrup, K. G., D'Agostini, S., van Langevelde, P. H., Siegler, M. A. \& Hetterscheid, D. G. H. Catalytic activity of an iron-based water oxidation catalyst: substrate effects of graphitic electrodes. ACS Catal. 8, 1052-1061 (2018).

10. Bucci, A. et al. An alternative reaction pathway for iridium-catalyzed water oxidation driven by cerium ammonium nitrate (CAN). ACS Catal. 6 , 4559-4563 (2016).

11. Wang, H. Y., Mijangos, E., Ott, S. \& Thapper, A. Water oxidation catalyzed by a dinuclear cobalt-polypyridine complex. Angew. Chem. Int. Ed. 53, 14499-14502 (2014).

12. Du, H. Y., Chen, S. C., Su, X. J., Jiao, L. \& Zhang, M. T. Redox-active ligand assisted multielectron catalysis: a case of Co-III complex as water oxidation catalyst. J. Am. Chem. Soc. 140, 1557-1565 (2018).

13. $\mathrm{Ma}$, L. et al. Cerium(IV)-driven water oxidation catalyzed by a manganese(V)nitrido complex. Angew. Chem. Int. Ed. 54, 5246-5249 (2015).

14. Li, Y. Y., Ye, K., Siegbahn, P. E. M. \& Liao, R. Z. Mechanism of water oxidation catalyzed by a mononuclear manganese complex. Chemsuschem 10, 903-911 (2017).

15. Koepke, S. J., Light, K. M., VanNatta, P. E., Wiley, K. M. \& Kieber-Emmons, M. T. Electrocatalytic water oxidation by a homogeneous copper catalyst disfavors single-site mechanisms. J. Am. Chem. Soc. 139, 8586-8600 (2017)

16. Du, J. L., Chen, Z. F., Ye, S. R., Wiley, B. J. \& Meyer, T. J. Copper as a robust and transparent electrocatalyst for water oxidation. Angew. Chem. Int. Ed. 54, 2073-2078 (2015).

17. Duan, L., Fischer, A., Xu, Y., Sun, L. \& Isolated Seven-coordinate Ru(IV) dimer complex with $[\mathrm{HOHOH}]^{-}$bridging ligand as an intermediate for catalytic water oxidation. J. Am. Chem. Soc. 131, 10397-10399 (2009).

18. Kunz, V., Schulze, M., Schmidt, D. \& Wurthner, F. Trinuclear ruthenium macrocycles: toward supramolecular water oxidation catalysis in pure water. Acs Energy Lett. 2, 288-293 (2017).

19. Yu, F. S. et al. Control over electrochemical water oxidation catalysis by preorganization of molecular ruthenium catalysts in self-assembled nanospheres. Angew. Chem. Int. Ed. 57, 11247-11251 (2018)

20. Kagalwala, H. N. et al. Evidence for oxidative decay of a Ru-bound ligand during catalyzed water oxidation. ACS Catal. 7, 2607-2615 (2017).

21. Duan, L. et al. A molecular ruthenium catalyst with water-oxidation activity comparable to that of photosystem II. Nat. Chem. 4, 418-423 (2012).

22. Schulze, M., Kunz, V., Frischmann, P. D. \& Würthner, F. A supramolecular ruthenium macrocycle with high catalytic activity for water oxidation that mechanistically mimics photosystem II. Nat. Chem. 8, 576-583 (2016).

23. Wang, L., Duan, L., Wang, Y., Ahlquist, M. S. G. \& Sun, L. Highly efficient and robust molecular water oxidation catalysts based on ruthenium complexes. Chem. Commun. 50, 12947-12950 (2014).

24. Gersten, S. W., Samuels, G. J. \& Meyer, T. J. Catalytic oxidation of water by an oxo-bridged ruthenium dimer. J. Am. Chem. Soc. 104, 4029-4030 (1982).
25. Duan, L., Wang, L., Li, F., Li, F. \& Sun, L. Highly efficient bioinspired molecular Ru water oxidation catalysts with negatively charged backbone ligands. Acc. Chem. Res. 48, 2084-2096 (2015).

26. Tong, L. \& Thummel, R. P. Mononuclear ruthenium polypyridine complexes that catalyze water oxidation. Chem. Sci. 7, 6591-6603 (2016).

27. Sens, C. et al. A new Ru complex capable of catalytically oxidizing water to molecular dioxygen. J. Am. Chem. Soc. 126, 7798-7799 (2004).

28. Zong, R. \& Thummel, R. P. A new family of Ru complexes for water oxidation. J. Am. Chem. Soc. 127, 12802-12803 (2005).

29. Matheu, R. et al. Intramolecular proton transfer boosts water oxidation catalyzed by a Ru complex. J. Am. Chem. Soc. 137, 10786-10795 (2015)

30. Xie, Y., Shaffer, D. W., Lewandowska-Andralojc, A., Szalda, D. J. \& Concepcion, J. J. Water oxidation by ruthenium complexes incorporating multifunctional bipyridyl diphosphonate ligands. Angew. Chem. Int. Ed. 55, 8067-8071 (2016)

31. Shaffer, D. W., Xie, Y., Szalda, D. J. \& Concepcion, J. J. Lability and basicity of bipyridine-carboxylate-phosphonate ligand accelerate single-site water oxidation by ruthenium-based molecular catalysts. J. Am. Chem. Soc. 139, 15347-15355 (2017)

32. Kamdar, J. M. et al. Ruthenium complexes of 2,2'-bipyridine-6,6 '-diphosphonate ligands for water oxidation. Chemcatchem 8, 3045-3049 (2016).

33. Duan, L. et al. Insights into Ru-based molecular water oxidation catalysts: electronic and noncovalent-interaction effects on Their catalytic activities. Inorg. Chem. 52, 7844-7852 (2013).

34. Song, N. et al. Base-enhanced catalytic water oxidation by a carboxylatebipyridine Ru(II) complex. Proc. Natl Acad. Sci. USA 112, 4935-4940 (2015).

35. Tong, L., Duan, L., Xu, Y., Privalov, T. \& Sun, L. Structural modifications of mononuclear ruthenium complexes: a combined experimental and theoretical study on the kinetics of ruthenium-catalyzed water oxidation. Angew. Chem. Int. Ed. 50, 445-449 (2011)

36. Nair, V. \& Deepthi, A. Cerium(IV) ammonium nitrate - a versatile singleelectron oxidant. Chem. Rev. 107, 1862-1891 (2007).

37. Ngo, K. T. et al. Turning on the protonation-first pathway for electrocatalytic $\mathrm{CO}_{2}$ reduction by manganese bipyridyl tricarbonyl complexes. J. Am. Chem. Soc. 139, 2604-2618 (2017).

38. Daniel, Q. et al. Rearranging from 6-to 7-coordination initiates the catalytic activity: an EPR study on a Ru-bda water oxidation catalyst. Coord. Chem. Rev. 346, 206-215 (2017).

39. Zhan, S. Q., Zou, R. F. \& Ahlquist, M. S. G. Dynamics with explicit solvation reveals formation of the prereactive dimer as sole determining factor for the efficiency of $\mathrm{Ru}(\mathrm{bda}) \mathrm{L}_{2}$ catalysts. ACS Catal. 8, 8642-8648 (2018).

40. Zhan, S., Martensson, D., Purg, M., Kamerlin, S. C. L. \& Ahlquist, M. S. G. Capturing the role of explicit solvent in the dimerization of $\mathrm{Ru}^{\mathrm{V}}(\mathrm{bda})$ water oxidation. Catalysts. Angew. Chem. Int. Ed. 56, 6962-6965 (2017).

41. Zhan, S. Q. \& Ahlquist, M. S. G. Dynamics and reactions of molecular Ru catalysts at carbon nanotube-water interfaces. J. Am. Chem. Soc. 140, 7498-7503 (2018).

42. Lebedev, D. et al. The key $\mathrm{Ru}^{\mathrm{V}}=\mathrm{O}$ intermediate of site-isolated mononuclear water oxidation catalyst detected by in situ X-ray absorption spectroscopy. J. Am. Chem. Soc. 140, 451-458 (2018).

43. Matheu, R. et al. The role of seven-coordination in Ru-catalyzed water oxidation. ACS Catal. 8, 2039-2048 (2018).

44. Shatskiy, A. et al. Electrochemically driven water oxidation by a highly active ruthenium-based catalyst. Chemsuschem 12, 2251-2262 (2019).

45. Zhang, B. et al. Characterization of a trinuclear ruthenium species in catalytic water oxidation by $\mathrm{Ru}(\mathrm{bda})(\mathrm{pic})_{2}$ in neutral media. Chem. Commun. 52, 8619-8622 (2016)

46. Tamaki, Y., Vannucci, A. K., Dares, C. J., Binstead, R. A. \& Meyer, T. J. Oneelectron activation of water oxidation catalysis. J. Am. Chem. Soc. 136, 6854-6857 (2014).

47. Dolomanov, O. V., Bourhis, L. J., Gildea, R. J., Howard, J. A. K. \& Puschmann, H. OLEX2: a complete structure solution, refinement and analysis program. J. Appl. Crystallogr. 42, 339-341 (2009).

48. Bochevarov, A. D. et al. Jaguar: A high-performance quantum chemistry software program with strengths in life and materials sciences. Int. J. Quantum Chem. 113, 2110-2142 (2013).

49. Zhao, Y. \& Truhlar, D. G. The M06 suite of density functionals for main group thermochemistry, thermochemical kinetics, noncovalent interactions, excited states, and transition elements: two new functionals and systematic testing of four M06-class functionals and 12 other functionals. Theor. Chem. Acc. 120 215-241 (2008).

50. Grimme, S., Antony, J., Ehrlich, S. \& Krieg, H. A consistent and accurate ab initio parametrization of density functional dispersion correction (DFT-D) for the 94 elements H-Pu. J. Chem. Phys. 132, 154104-154119 (2010).

51. Goerigk, L. \& Grimme, S. A thorough benchmark of density functional methods for general main group thermochemistry, kinetics, and noncovalent interactions. PCCP 13, 6670-6688 (2011). 
52. Hay, P. J. \& Wadt, W. R. Abinitio effective core potentials for molecular calculations - potentials for $\mathrm{K}$ to Au including the outermost core orbitals. J. Chem. Phys. 82, 299-310 (1985).

53. Olsson, M. H. M. \& Warshel, A. Solute solvent dynamics and energetics in enzyme catalysis: The $\mathrm{S}_{\mathrm{N}} 2$ reaction of dehalogenase as a general benchmark. J. Am. Chem. Soc. 126, 15167-15179 (2004).

54. Berendsen, H. J. C., Vanderspoel, D. \& Vandrunen, R. Gromacs - a messagepassing parallel molecular-dynamics implementation. Comput. Phys. Commun. 91, 43-56 (1995).

55. King, G. \& Warshel, A. A surface constrained all-atom solvent model for effective simulations of polar solutions. J. Chem. Phys. 91, 3647-3661 (1989).

56. Blaha-Nelson, D., Kruger, D. M., Szeler, K., Ben-David, M. \& Kamerlin, S. C. L. Active site hydrophobicity and the convergent evolution of paraoxonase activity in structurally divergent enzymes: the case of serum paraoxonase $1 . J$. Am. Chem. Soc. 139, 1155-1167 (2017).

57. Lemkul, J. A. \& Bevan, D. R. Assessing the stability of alzheimer's amyloid protofibrils using molecular dynamics. J. Phys. Chem. B 114, 1652-1660 (2010).

58. Kumar, S., Bouzida, D., Swendsen, R. H., Kollman, P. A. \& Rosenberg, J. M. The weighted histogram analysis method for free-energy calculations on biomolecules. I. The method. J. Comput. Chem. 13, 1011-1021 (1992).

\section{Acknowledgements}

We would like to thank National Natural Science Foundation of China (21771098 and 21777045), the State Key Laboratory of Fine Chemicals (KF1802), Shenzhen R\&D Fund (KQTD20180411143418361), Guangdong Provincial Key Laboratory of Energy Materials for Electric Power (2018B030322001), the Swedish Research Council (2017-00935), the Knut and Alice Wallenberg Foundation (KAW 2016.0072), and the China Scholarship Council (CSC). All calculations were performed on resources provided by the Swedish National Infrastructure for Computing (SNIC) at the National Supercomputing Center in Linköping, Sweden.

\section{Author contributions}

J.Y. and L.W. performed experiments. S.Z. and M.S.G.A. performed the computational calculations. H.Z. and H.C. contributed to the discussion of the paper. L.D. and L.S. conceived and directed the project and wrote the paper. All authors discussed the results and commented on the manuscript.

\section{Funding}

Open Access funding provided by Kungliga Tekniska Hogskolan.

\section{Competing interests}

The authors declare no competing interests.

\section{Additional information}

Supplementary information is available for this paper at https://doi.org/10.1038/s41467 020-20637-8.

Correspondence and requests for materials should be addressed to L.D. or L.S.

Peer review information Nature Communications thanks Javier Concepcion and the other, anonymous, reviewer(s) for their contribution to the peer review of this work.

Reprints and permission information is available at http://www.nature.com/reprints

Publisher's note Springer Nature remains neutral with regard to jurisdictional claims in published maps and institutional affiliations.

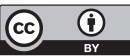

Open Access This article is licensed under a Creative Commons Attribution 4.0 International License, which permits use, sharing, adaptation, distribution and reproduction in any medium or format, as long as you give appropriate credit to the original author(s) and the source, provide a link to the Creative Commons license, and indicate if changes were made. The images or other third party material in this article are included in the article's Creative Commons license, unless indicated otherwise in a credit line to the material. If material is not included in the article's Creative Commons license and your intended use is not permitted by statutory regulation or exceeds the permitted use, you will need to obtain permission directly from the copyright holder. To view a copy of this license, visit http://creativecommons.org/ licenses/by/4.0/.

(C) The Author(s) 2021 